\title{
TRANSFORMATION OF SCIENCE \& TECHNOLOGY SYSTEMS INTO SYSTEMS OF INNOVATION IN CENTRAL AND EASTERN EUROPE: THE EMERGING PATTERNS AND DETERMINANTS ${ }^{1}$
}

\section{Slavo Radosevic}

\begin{abstract}
This paper explores patterns of transformation of socialist S\&T systems into postsocialist systems of innovation and their determinants. First, we reinterpret the socialist period from a systems of innovation perspective by revisiting the socialist S\&T system and by pointing to its general features as well as to its national and sectoral variations. Second, we develop a conceptual model to help to understand the factors that are determining the emergence of systems of innovation. Systems of innovation in CEE are being shaped through the interaction of micro, sectoral, national and regional determinants. At present, sectoral differences and micro-specific determinants seem to be the strongest in this process. The process of development and selection of network organisers is at the core of the emergence of systems of innovation in central and eastern Europe (CEE). The most active network organisers are foreign firms. New production and innovation networks, especially in central Europe, are most often foreign-led.
\end{abstract}

\footnotetext{
${ }^{1}$ Research which formed the basis for this paper is part of the project 'Restructuring and re-integration of S\&T systems of economies in transition' funded by the EC - DG XII Targeted Socio Economic Research Programme. Previous versions of this paper were presented at the TSER project workshop at Sussex University (June 1997), ASEAT Conference at UMIST Manchester (September 1997) and at the Annual Conference of the European Association for Evolutionary Political Economy (Athens, November 1997). I am grateful to Birgit Andersen, Jan Annerstedt, Keith Pavitt, Werner Meske, Christian von Hirschhausen and three anonymous referees for valuable comments on the previous versions of this paper. However, all remaining errors remain my responsibility.
} 


\section{Introduction}

The main problem of socialism was in its dynamic efficiency or (in)ability to innovate in the long-term (Hanson and Pavitt, 1987). As Murrel (1990) shows central and eastern European countries' (CEECs) foreign trade was quite in line with expected comparative advantages thus indicating that allocative efficiency was not the main problem under socialism. ${ }^{2}$ This lesson from the past equally applies today. The prospects for catching-up of the post-socialist CEECs with the EU economies will depend on their ability to generate industrial and technical change.

The generation of industrial and technical change embodied in development and diffusion of new innovative products and processes requires significant institutional change and the scale of institutional change in CEECs is massive. However, institutional change cannot be judged per se, without taking into account its effects on technical change and growth. As argued by Kekic (1996) transition, understood as the institutional transformation towards a market economy, makes sense only if it is encompasses economic performance as well as institutional change. Institutional transformation towards a market economy that does not bring appreciable economic benefits to the population cannot be pursued indefinitely within a democratic framework (ibid.).

The link between institutional change and economic recovery in CEECs is a controversial one. The European Bank for Reconstruction and Development (EBRD, $1994,1995,1996)$ assessments of transition progress suggest that fast reformers also enjoy the benefits of economic recovery. On the other hand, based on the analysis of institutional reform over the last five years, Kekic (1996) comes to the conclusion that there is 'a weak negative link between the pace and extent of economic reform and

\footnotetext{
${ }^{2}$ CEECs should be interpreted as countries of central, eastern Europe and of the former Soviet Union.
} 
the depth of output decline in the transition once initial conditions and the external environment are taken into account' (p. 21). Obviously, the relationship between long-term growth and institutional change is rather complex. This complexity arises from the need for the institutional set up to be conducive not only to allocative efficiency but also to adaptability. ${ }^{3}$ While specific institutional reform may be appropriate in the short-term it may be inappropriate in the long-term. For example, in the short term, mass privatisation may be a good solution, but it will produce a higher cost in terms of corporate governance problems over the long-term. Long-term recovery does not necessarily follow simply from progress in market reforms or, at least, the link is not straightforward. ${ }^{4}$

These introductory remarks point to the complexity of the relationship between technical and institutional change in understanding the growth prospects of CEECs. The analysis of industrial and technical change should involve not only analysis of Science and Technology (S\&T) inputs and outputs but also a quite elaborate institutional analysis as it is through institutions that innovation processes are mediated. A perspective in which technical and institutional change are explicitly linked is that of systems of innovation (Nelson, 1993; Lundvall, 1992; Edquist; 1997). Based on this perspective our argument is that long-term growth of the CEECs will be accompanied by the emergence of different systems of innovation (SI) (inter-firm, sectoral, regional, national and global). ${ }^{5}$

\footnotetext{
${ }^{3}$ By adaptability I mean the ability to promote technical change through diversity and co-existence of different organisational forms.

${ }^{4}$ Recovery may not follow from the type of 'shallow' institutional change (trade liberalisation, price liberalisation) but may follow from 'deeper' institutional change (enterprise restructuring; banking reform; effectiveness of legal system). Economies may recover in the short-term but may fail in the medium- and long-term because of incompatibilities between technical and institutional change.

${ }^{5}$ For an overview and critique of different definitions of systems of innovation see Radosevic, $1998 \mathrm{~b}$.
} 
A systems of innovation perspective applied here to the post-socialist context has certain distinctive advantages when it comes to understanding the prospects for longterm growth of the CEEs.

First, institutional change is not seen from some external optima or static allocative efficiency criteria but from the point of view of how it promotes technological and structural change. Emerging organisational forms are judged by the way in which they are conducive to technical change and learning in the economy. Such a perspective emphasises adaptability rather than static efficiency as the main criterion in evaluating institutional set up. As argued by Grabher and Stark (1997), a diversity of organisational forms linked through exchange of resources and information allows for a better adaptability of the economy than a situation in which organisations are of only one type. Finally, the historical experience of socialist economies with their poverty of enterprise forms and other business organisations is the best proof of the relevance of this proposition.

Second, a system of innovation perspective is, in essence, a mezzo perspective which goes beyond the micro/macro dichotomy. In this perspective individual firms are seen as part of the broader networks of firms with whom they co-operate and compete. Their growth is also closely connected to the available institutional sectoral support (see Nelson, 1997 for the role of sectoral support systems).

However, the focus on the mezzo level does not mean that micro and macro (national) factors do not play a sometimes decisive role in the growth process. Firm specific cognitive and competence gaps result in different firm responses from the same set of macroeconomic incentives. ${ }^{6}$ On the other hand, national level variables may play such an important role that it is possible to talk about national systems of

\footnotetext{
6 See Swaan, 1995 for application of this in a post-socialist context.
} 
innovation (Freeman, 1987). While national level variables are important, it is firms' diverse responses that take advantage of them.

The SI perspective is indeterminate regarding the level at which SI operates. SI can be inter-firm, regional, national or global (see Edquist, 1997). What constitutes a mezzo perspective is the view that enterprises operate as part of a network which is a larger unit of analysis than the firm. Networks consist of actors (customers, subcontractors, infrastructure, suppliers); competencies or functions; and links or relationships. Competencies for technical change and growth do not reside only in individual firms but are distributed throughout the network of actors and their links or relationships.

Third, the debate on post-socialist transformation stresses discontinuity assuming that market institutions can be created from scratch (Blanchard et al, 1994). In being historical the SI perspective accords with those views that hold that the discontinuity of transition from planned to market is not as large as is commonly believed. In the mainstream perspective all legacies of the past are seen as obstacles and deterrents to change. 'Putting new institutions in place' is seen as crucial for making transition successful. Contrary to this SI perspective and compatible with the evolutionary perspective on transition, is the view that transformation of CEECs is an open ended process whereby the creation of institutions is itself a process subject to economic laws (Rapazcynski, 1997). Legacies are seen as being dual in nature being simultaneously a 'resource' as well as a 'constraint' (Grabher and Stark, 1997) or a 'heritage' and a 'source of creation' (Kontkiewicz-Chaculska and Phan, 1996). Path dependency combined with radical change creates an evolutionary process in which legacies but also novelty play a role in future outcomes. 
Fourth, any economic and technical change is a social process whereby new institutions in order to be viable have to be embodied in social practice (Granovetter, 1985). A process of economic and technical embodiment is accompanied by creation and destruction or persistence of the informal networks that support or hinder change. Learning is not only a process of acquisition of technical and organisational competencies but also a process of the creation of social networks. ${ }^{7}$ These are indispensable for putting technical and organisational competencies into productive use (Kuznetsov, 1997b). ${ }^{8}$

Based on the above four propositions I would argue that catching up by the CEECs is closely related to the emergence of systems of innovation be they inter-firm, sectoral, regional, national or global. The main concern is the transformation of the socialist S\&T system into diverse patterns of emerging systems of innovation (SIs) in the post-socialist economies. The notion of a S\&T system reflects well the institutional separation of $R \& D$ and innovation activities from production in socialism while the notion of SI reflects equally well the diversity of patterns of innovation which will develop in the post-socialist period. The basic perspective put forward is that in post-socialism we find a strong transformation of patterns of technical change (sources, knowledge base, appropriability). From one sector (the S\&T system) innovation activities are being embedded in a multiplicity of emerging systems of innovation. From a sectorally uniform structure, in the sense that patterns of innovation, $R \& D$ organisation and sources of technical change were similar across all industrial sectors, the system moves towards a multiplicity of SI. Since innovation

\footnotetext{
${ }^{7}$ For application of social networks or social capital perspective in the context of CEECs see Kolankiewicz (1996).

${ }^{8}$ Any system of innovation is characterised by a specific learning regime. This is defined by Kuznetsov (1997b) as the specific self-reinforcing configuration of knowledge networks (industrial districts, industrial groups, large firms).
} 
was separated from production and the market, the S\&T system was self-contained making it difficult to talk about system of innovation in socialist economies.

Diverse patterns of emerging SI are seen here as an outcome of mutual interaction of historical heritage, especially organisational path-dependency, recombination of existing competencies into new organisational forms, and radical economic change generated by new incentives and opportunities.

This paper addresses two main questions. First, are there any systematic patterns in the process of transformation of socialist S\&T systems into post-socialist systems of innovation? Second, what determines these patterns?

The paper is organised in the following way. Section 2 revisits the socialist S\&T system by pointing to its general model features as well as to its national and sectoral variations. The main features of socialist production/innovation networks and the indispensable role of informal networks in 'getting things done' are outlined. In the third part micro-, sectoral-, national- and regional determinants of the emergent systems of innovation in the post-socialist period are examined. Two propositions are developed. First, that the systems of innovation in CEECs are emerging through the interaction of micro-, sector-, national- and regionally- specific factors. Second, for the time being, micro- and sector-specific determinants are the strongest influences shaping the emerging systems of innovation. In Section 4 the potential network organisers in CEE are discussed. Among the emerging network organisers foreign firms are, at present, the most active, especially in central Europe. Section 5 summarises the main conclusions.

\section{The socialist S\&T system: the general model and its variations}


The multiform nature of innovative activities and their sectoral specificity are reflected in diverse sources of innovation as well as forms of appropriations of innovation rents. However, under socialism this multiplicity of patterns of innovation was radically reduced. Externalised $R \& D$ and engineering $(R \& D \& E)$ was the main source of innovation in all sectors while appropriation of innovation rents was irrelevant as technology was essentially considered to be a 'free good' (Hanson and Pavitt, 1987). Users' learning ('learning by using') and learning resulting from production ('learning by doing') were disproportionately less present as sources of innovation when compared to the innovation inputs from the externalised $R \& D$ system (supply push). This section outlines a general model of the socialist S\&T system and its variations. This is included not just for its historical value but with a view to showing, first, how path-dependency comes about in the post-socialist context and, second, which actors, competencies and links of the old system are now being recombined in the transition process.

\subsection{General model of the socialist $S \& T$ system}

By abstracting much of the inter-country differences the post-socialist transformation in R\&D and innovation (RDI) can be seen as a shift from the S\&T system dominated by one sector ('science and scientific services') towards a diversity of sectoral systems of innovation. Under socialism most technical change was pushed from one institutional sector, given a different name in different countries but which was essentially a grouping of $R \& D$ institutes and other related activities, such as technology services, micro-production and support activities. This sector was considered as a separate branch which, through vertical links, was connected with industrial enterprises. This sector was involved in activities far beyond R\&D 
including design, engineering and often trouble-shooting activities. Since innovation and production were two quite separate activities the whole process was managed by government ministries and central institutes.

R\&D activities were controlled by a separate chain of command and by separate channels of finance from mass production (OECD, 1969, p. 425). The system was primarily 'production oriented' which influenced not only the provision of development facilities, but also the attitude of the industrial enterprise with regard to technical innovation (ibid., p. 427).

The innovation process was organised on the basis of the linear innovation model with the main push coming from externalised R\&D\&E towards production, which was seen merely as the implementation of designs developed elsewhere. Production and users were not considered to be sources of improvements and innovations.

For an understanding of the nature of the innovation process in socialism it is important to bear in mind that enterprises in the Western sense did not exist under socialism (von Hirschhausen, 1996). The enterprises that existed were production and not business units. Business functions, like marketing, finance and $R \& D$, were either rudimentary and developed 'in house', or were entirely 'outsourced', either to ministries or to other organisations (foreign trade organisations, branch institutes, ministries, industry directorates). Combinates were polyfunctional units that also provided welfare services for the local community and in which elements of political control were strongly present (see von Hirschhausen, 1996).

In market-economies technology is a firm-specific, meaning that much embodied knowledge is idiosyncratic, reflecting accumulated learning-by-doing and a specific organisational context. This essential feature of technology, not products, qualifies enterprises as institutions that are transforming technology into products (von 
Tunzelmann, 1995). This transformation in socialism was performed across a hierarchy or network of applied R\&D and design bureaux. Innovation tasks were located in branch institutes and design bureaux with very little technological effort being practised at the shop-floor level (OECD, 1969). The linear innovation process was vertically segmented while a ministerial organisation of branches introduced additional horizontal segmentation (Hanson and Pavitt, 1987, von Tunzelmann, 1995, Chapter 9). R\&D was not organised as an 'in-house' activity, or R\&D in industry, but as R\&D for industry (Radosevic, 1998). This meant that much technological activity was oriented towards the needs of industry and yet was outside the enterprises. Weak feedback from production and use of products as well as the diffusion of transformation of technology into products across the hierarchy deprived enterprises of the ability to accumulate knowledge. Knowledge was accumulated more in design and engineering institutes, which acted as problem solvers, often on a daily basis, for enterprises.

The S\&T system was very much branch oriented as confirmed by the extent of intersectoral flows of innovation which were very modest. Table 1 indicates the extent to which technology flows were enclosed within individual sectors. Branch orientation of the S\&T system was reinforced further by inter-departmental barriers to co-ordination of R\&D. However, the administrative barriers between the R\&D system and industrial production were reinforced by the system of planning and led to the reluctance of the factory to innovate. 
Table 1: Intersectoral movements of Soviet inventions (Percentage of number of inventions used inside the same sector)

\begin{tabular}{lcl}
\hline Sector & $1973-74$ & 1981 \\
\hline Civil Machine building & 0.56 & 0.68 \\
Closed Civil machinery building & 1 & - \\
Construction & 0.63 & 0.56 \\
Defence industry & 0.83 & 0.73 \\
Light and food industry & 0.77 & 0.73 \\
Other & 0.51 & 0.79 \\
Other civil. heavy industry & 0.69 & 0.69 \\
Power Gen. and Transmission & 0.7 & 0.4 \\
Transport & 0.6 & 0.74 \\
Education and Science & 0.17 & 0.52 \\
\hline
\end{tabular}

Source: Recalculated based on Martens, John (1991)

In summary, in socialism transformation of technology into products, was dispersed across a hierarchy. Enterprises were merely production units and thus not fully developed knowledge accumulating institutions. The separation of technology development from production meant that innovation infrastructure institutions played a much more important role in the creation of technology and the main systemic defect was in the weak technology creation capability of enterprises. As technology is primarily a firm-specific asset the consequence of this systemic defect was that the links between R\&D and production were generally weak. However, functional oneway links running from $R \& D$ to production were more intensive. In some cases they led, as will be argued in the next section, to quite close relationships between R\&D\&E organisations and enterprises, despite formal barriers.

Second, these were links only in investments and in solving major production bottlenecks but not in continuous improvements. This was the result of production not being seen as an innovative activity and the fulfilment of planing tasks hindered the resolution of all the complications that innovation would bring. Enterprises, which were treated as organisations that only implemented designs created elsewhere, could 
not be regarded as a source of demand pull for innovation. In addition, the closed character of most socialist economies induced much 'reinventing-the-wheel' type technology effort and deprived the economy of the numerous growth possibilities that openness can provide through foreign direct investment (FDI), subcontracting, and alliances.

\subsection{Variations within the general model of the socialist $S \& T$ system}

The general model of the socialist S\&T system outlined above describes the essential features of innovation activities in socialist economies but does not reflect significant sectoral and national differences or differences over time in socialist S\&T systems. The argument here is that these differences were important and that they strongly influenced modes of adjustments as well as the scale of problems in transformation of S\&T in individual CEECs.

\subsubsection{National differences}

National differences between S\&T systems of socialist countries were most pronounced in the following respects:

- in the degree to which R\&D activities were carried out within industrial enterprises (share of 'in-house' R\&D);

- in the degree to which R\&D was carried out in extra-mural organisations (share of industrial institutes);

- in the degree to which universities played a teaching vs. research role (share of higher education institutions in gross expenditures for R\&D); 
- in the degree to which the role and functions of Academies of Sciences were different (Academies of Sciences as government bodies or loose associations of institutes) $; 9$

- in the degree to which economies were open or closed for S\&T co-operation (CMEA membership and progress in socialist economic reforms);

These differences taken together indicate the degree to which countries were close to the Soviet R\&D model (see Gokhberg, 1997). It is beyond the scope of this paper to delve in greater detail into these differences. Table 2 indicates the most important national difference - the degree to which $R \& D$ activities were extra- or intra-mural through the institutional structure of the foreign US patent data.

Table 2: Number of the foreign US patents by institutional sectors, 1969-1994 (\%)

\begin{tabular}{lrrrrrrr}
\hline & $\begin{array}{l}\text { Former } \\
\text { Sov Un }\end{array}$ & Bulgaria & $\begin{array}{c}\text { Former } \\
\text { Czecho- } \\
\text { slovakia }\end{array}$ & Hungary & Romania & Poland & $\begin{array}{c}\text { Former } \\
\text { Yugoslavia }\end{array}$ \\
\hline Acad. of Science. & 15 & 4 & 27 & 3 & 0 & 7 & 3 \\
Enterprises & 11 & 49 & 41 & 81 & 25 & 24 & 62 \\
Industrial inst. & 56 & 40 & 25 & 12 & 50 & 37 & 6 \\
Government & 0 & 3 & 0 & 0 & 19 & 0 & 0 \\
Universities & 5 & 0 & 4 & 2 & 5 & 24 & 1 \\
Foreign & 12 & 4 & 1 & 2 & 1 & 8 & 28 \\
Non-classified & 0 & 0 & 1 & 0 & 0 & 0 & 0 \\
\hline
\end{tabular}

Source: Radosevic and Kutlaca (1999)

Table 2 indicates four groups of countries with respect to the share of enterprises vs. extra-mural organisations in US patenting. Hungary and former-Yugoslavia had by far the highest share of enterprise patenting. Bulgaria and Czechoslovakia had patents both from enterprises and industrial institutes while Polish and Romanian patenting was dominated by extra-mural patenting. The most Soviet like model in terms of

${ }^{9}$ For national differences in the role of and functions of Academies of Sciences see Balazs (1997). 
patenting can be found in the Soviet Union itself where enterprises were marginal players. ${ }^{10}$

\subsubsection{Sectoral differences in innovation activities}

There were also substantial variations between industries in the organisation of R\&D. As argued by the OECD (1969) study on the Soviet S\&T some industries conformed almost entirely to the standard pattern of the socialist R\&D-production chain while the others departed from it. The biggest difference was between priority (defence, aerospace) and civil sectors.

Priority sectors In priority sectors the defects of the system were overcome not through a different organisational model but through effective central co-ordination, control, flexibility in planning, and government authority in enforcing priorities which were combined with a much more generous supply of development and experimental production facilities than was the case in civil sectors. Effective co-ordination led to the overcoming of inter-departmental or intra-departmental barriers while government authority removed the inhibitions usually placed on innovation by production-oriented planning (OECD, 1969). In addition, the defence sector's single powerful customer (Ministry of Defence) was able to explicitly dictate technical and economic requirements and develop close co-operation with the military industry (Amman and Cooper, 1982: 353).

Priority sectors show that formal networks were functioning despite obvious systemic weaknesses. However, how these systemic defects could be overcome in

\footnotetext{
${ }^{10}$ For analysis of the CEE US foreign patenting see Radosevic and Kutlaca (1999).
} 
non-priority, civil sectors is less clear. The argument here, which draws on the works of Russian scholars, is that this was possible only through informal links.

Differences between civil sectors Explanations for the sectoral differences in organisation of R\&D among civil sectors are not straightforward. The authoritative OECD (1969) study, which also tried to analyse sectoral differences, indicates that these differences were determined by: technological, historical and organisational factors. In areas where it was difficult to transform the experimental model into a prototype, for example electronics, the R\&D pattern was more traditional. Historical and specific circumstances in which particular arrangements grew up, also played an important role, especially that of powerful and entrepreneurial individuals. Organisational factors were taken into consideration when a process was used in a wide variety of enterprises. Organisational complexity, as well as economies of scale, shifted the responsibility for development to a major research institute.

Based on the OECD (1969) study it is possible to distinguish between three sectoral variants of the general pattern of $R \& D$ and innovation organisation: the traditional, the combined and the factory based pattern.

\section{Figure 1}


Different variants of the Soviet innovation mode (based on the OECD, 1969)

TRADITIONAL PATTERN

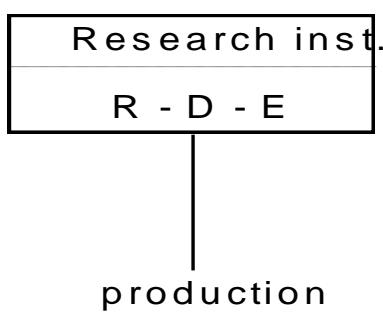

Examples: iron \& steel

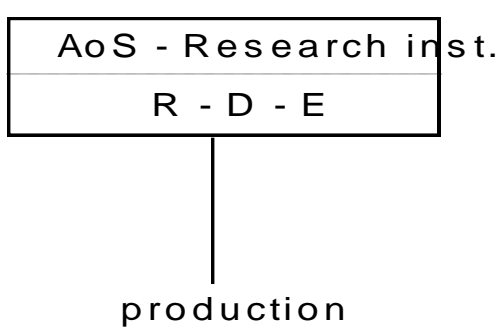

chemical indus 1

\section{COMBINED PATTERN}

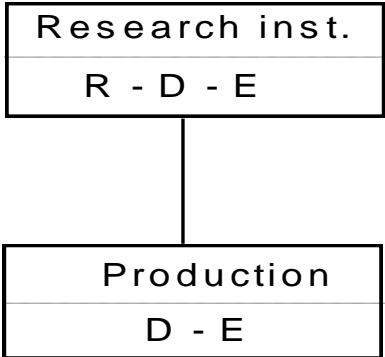

Examples: machine tools

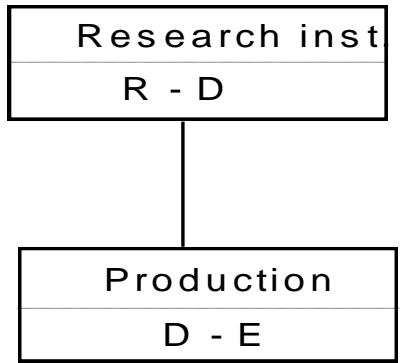

machine

FACTORY BASED PATTERN
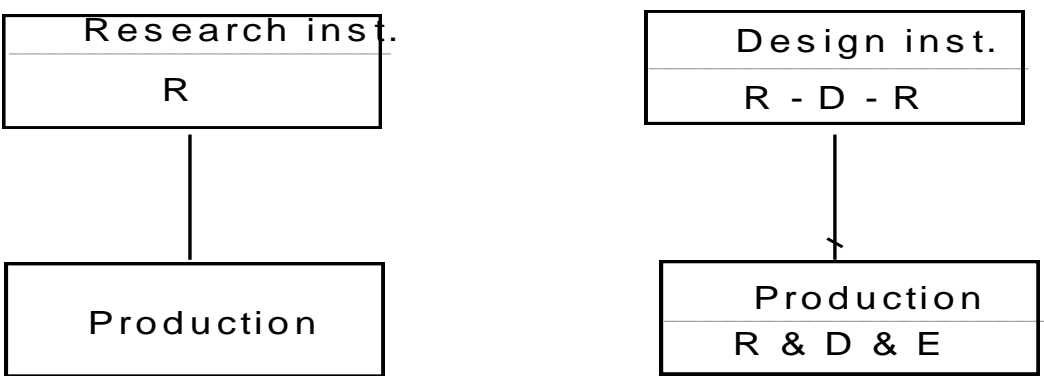

Examples: water turbines

'Mos

AoS $=$ Academies of Sciences R $-\mathrm{D}-\mathrm{E}=$ Research, development and engineering 
The traditional pattern is the one in which the research institute might handle the whole of a project from the research stage to the industrial prototype stage. In the combined pattern research is centralised but design and development are decentralised. The factory based pattern was present on a limited scale. Some design bureaux, in spite of their independent status, in practice simply worked as if they were design bureaux of the factories to which they are attached. At the same time the factories themselves were responsible for a considerable amount of original design and development work.

Although figure 1 indicates the existence of the three distinctive patterns it is not possible to draw too much out of these differences due to two factors. First, as concluded by the OECD (1969) in the vast majority sectors the dominant pattern was the traditional one. Second, this by itself does not mean that the organisational variation was either a disadvantage or an advantage. Individuals that were able to mobilise strong support could compensate for the disadvantages of formal organisations by bringing together all the actors in a joint operation. For example, although $\mathrm{R} \& \mathrm{D}$ and innovation in the iron and steel industry was organised along the traditional pattern its US patenting record is much better than that for other sectors (see Radosevic and Kutlaca, 1999).

\subsubsection{Combinates: building horizontal structures}

A third element of variations in the general model of the socialist S\&T system is the changes in the system itself over time. Indeed, the socialist system was under permanent reform although most analysts from that period agreed that very little real change actually occurred. 
The chief benefits from these groupings of enterprises were in the streamlining of the planning system by a reduction in the number of units to be controlled, economies of scale, and encouragement given to innovation. On the other hand, these organisational structures were the result of the deficiencies of the centralised system and an unwillingness to adopt a fully decentralised system. This allowed the reduction in the number of units to be centrally directed and allowed ministries to concentrate on 'strategic' tasks. Vertical integration allowed incorporation of the most important supplier enterprises, with the aim of improving the acute supply problems.

From an innovation perspective, the introduction of horizontal amalgamations of enterprises, here termed combinates but given different names in different countries (see table 3 ), was a very important institutional innovation. ${ }^{11}$ Combinates enabled closer links between enterprises and R\&D by avoiding to a certain extent central coordination.

\footnotetext{
${ }^{11}$ Chandler (1993) describes them 'as the most significant institutional innovation in the microenvironment of the USSR after Stalin put the central planning system into operation' (p. 333)
} 
Table 3: Horizontal groupings of enterprises in the socialist period in the CEE countries

\begin{tabular}{llll}
\hline Country & Organisational forms & $\begin{array}{l}\text { Year of } \\
\text { Introd. }\end{array}$ & Description \\
\hline USSR & $\begin{array}{l}\text { Production associations (proizvodstvennoe } \\
\text { obedineniye) } \\
\text { Science - production associations (NPO) } \\
\text { Industrial (administrative) associations }\end{array}$ & 1973 & $\begin{array}{l}\text { In 1984 they accounted for about half of both industrial output and } \\
\text { employment }\end{array}$ \\
\hline DDR & Combinates & 1969 & $\begin{array}{l}\text { Decree of 1979 set up combines as the basic production unit. In } \\
1981 \text { there was 133 combinates with an average 25 employees and } \\
\text { 20-40 enterprises. }\end{array}$ \\
\hline Czechoslovakia & Industrial associations (VHJ) & 1958 & $\begin{array}{l}\text { In mid-1970s VJH became the basic production unit. 'It usually } \\
\text { involved a horizontal integration of enterprises, either a koncern (a } \\
\text { large enterprise alone or one linked with smaller ones) or a trust } \\
\text { (where enterprises of comparable size are merged), but there was } \\
\text { also the vertically integrated kombinat' (Jeffries, 1993: 248). }\end{array}$ \\
\hline Romania & $\begin{array}{l}\text { A country-wide horizontal integration of one large } \\
\text { enterprise with smaller ones (centrala) }\end{array}$ & 1969 & $\begin{array}{l}\text { Very strong centralization where the central was responsible for } \\
\text { imposing disaggregated plan targets on constituent enterprises. }\end{array}$ \\
\hline $\begin{array}{l}\text { Poland } \\
\text { Large economic organisation (wielkie organizacje } \\
\text { gospodarcze, WGO) }\end{array}$ & 1973 & $\begin{array}{l}\text { From 1973-76 WGO enjoyed high degree of independence followed } \\
\text { by recentralization after 1976 }\end{array}$ \\
\hline Bulgaria & $\begin{array}{l}\text { State economic organisations (durzhavenski } \\
\text { stopanski obedinenniya, DSO) }\end{array}$ & 1963 & $\begin{array}{l}\text { In 1970 the number of } D S O \text { reduced from } 120 \text { to } 64 \text { (35 in industry) } \\
\text { In 1980/81 the initiation of small state-owned, semi-autonomous } \\
\text { enterprises within } D S O \text { began. }\end{array}$ \\
\hline Hungary & $\begin{array}{l}\text { Large state enterprises were members of trusts } \\
\text { or associations }\end{array}$ & - & $\begin{array}{l}\text { After 1968 most state enterprises were freed from compulsory } \\
\text { membership of trusts and associations. In 1982 'private workshop } \\
\text { partnerships' were allowed in state enterprises. }\end{array}$ \\
\hline
\end{tabular}

Source: based on Jeffries (1993), Grabher (1997), McDermott (1997), Smith (1981) 
As von Hirschhausen (1996, p. 85-88) concludes, horizontal integration which became possible within combinates (often the whole branch was integrated) especially in Czechoslovakia, led to the attachment of a number of $R \& D$ organisations to one combinate. However, the creation of these monopolies and the diminution of crossbranch co-operation and confusion in relations between enterprise and combine or central company had adverse effects on innovation.

\subsubsection{Weak and strong links and informal networks in socialism}

It has been pointed out that the creation of technology and transformation of technology into products was, in socialism, distributed across socialist hierarchies. As different business functions were 'outsourced' to different organisations the operation of the system was dependent on all the actors involved. Actors were linked through hierarchical relationships which were often very complex. The previous sections have illustrated the diversity of these links in terms of R\&D - production. However, despite this diversity there were some common systemic features regarding the strength of links within these hierarchies.

The weak links were:

- those between different ministries or different branches (see table 1);

- those between foreign sellers and domestic users;

- lack of feedback from user enterprise to R\&D and design institutes. 
However, there were functional one way links between $R \& D$ and design institutes. In such a situation the biggest problem was the system integration at product level, and process (network) integration at enterprise level. ${ }^{12}$

By system integration at product level we mean that production and continuous improvement require integration of different functions (finance, $R \& D$, engineering, procurement, production, sale) whose integration is essential to innovation dynamics. By process integration at the firm level we mean that production and innovation has to be organised across several tiers of suppliers which are all involved to different degrees, not only in production, but also in innovation.

In market economies these integrative functions are carried out by producers or users. In the socialist period it was officially government administration or, in practice, central or design institutes that were taking on some of the functions of a network organiser. There was some system integration capability in institutes, but only for products not for processes. Design institutes also had much better international links and a better understanding of technological trends, the possibilities for domestic industry and even markets (see Alange et al, 1995 for the case of the Russian machine tools sector). Since users did not initiate work the most important actors were design institutes, except in the case of the defence sector where the Ministry of Defence was a competent user and initiated new developments. Customers or users were not strong initiators of change. Even when they had the money to make their own contracts in R\&D (especially in the 1980s) they were not very concerned about the final results.

System integrators at the process level were ministries. Organisation of processes that involved multi-technology products was especially difficult if not impossible as

${ }^{12} \mathrm{As}$ business press indicate this is one of the biggest weaknesses of enterprises in post-socialist period. 
this could involve several ministries. Sometimes this led to several parallel developments that resulted in a sort of rivalry.

Foreign supplier - domestic user links Links between domestic users and producers were weak in the socialist economy. Since the producer was not actually in control of all the elements of production (design, price, distribution) the whole idea of learning by using (von Hippel, 1990) was, except in the defence sector, alien to the socialist economy. However, export and import were the points where domestic organisations could be exposed to some learning by importing effects. Sandberg (1989) shows that the Soviets tried to overcome their generally very poor learning-by-assimilating capability by creating close and long-term collaboration with a selected group of accredited Western suppliers that could help them not only with technical preinvestment adaptations, but also in reaching capacity levels and providing for further diffusion. ${ }^{13}$ However, the effects of this were seriously constrained in the more closed Soviet type economies where contact between foreign and domestic sellers was mediated through foreign trade organisations (FTOs) (see figure 2).

\section{Figure 2:}

Relationship between foreign and domestic partners in 'classic' Soviet sys

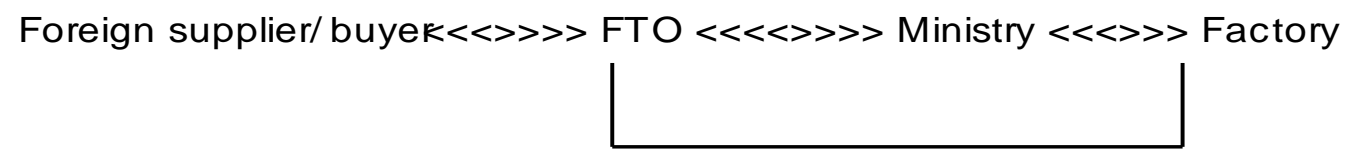

Initially, FTOs were responsible for handling all foreign trade contracts. Foreign companies were not allowed to have contact with other departments within the

\footnotetext{
${ }^{13}$ The more advanced Soviet industries were, the more successfully they learned from this collaboration (Sandberg, 1989).
} 
Ministry or with the factories. As Sandberg (1989) shows, long-term relationships between FTO and foreign suppliers were crucial for successful business partnering. The process of the transformation of this system into a more direct relationship was gradual. First, Soviet ministries started to lose the monopoly in their particular field of activity to the advantage of republic ministries. Then republic ministries started to bypass Soviet FTOs and to undertake trade negotiations on their own. From 1988 direct contacts between foreign suppliers and domestic factories have been allowed in the USSR. By a decree in 1988 foreign firms were permitted to do business directly with Soviet producers without having to go through an FTO. (On this point see Wit and Monami, 1993, and Salmi and Moller, 1993.)

In all the other CEE countries, with the exception of Romania, direct trading had been allowed for a long-time and Jeffries (1993: 247) reports that in Czechoslovakia, even after the 1968 invasion, some enterprises were able to continue direct trading with foreign partners. This, for example in Hungary, led to the strongly dichotomised treatment of eastern and western markets by domestic producers (see Hare and Oakey, 1993 on process machinery). Selling in 'soft' eastern markets probably led to fewer inputs in terms of learning by exporting. Factories were involved, through FTOs, in the technical negotiations while FTOs were responsible for the financial aspects of negotiations and to a great extent led the organisation of the entire import or export process.

\subsubsection{1. 'Getting things done': informal networks in socialism}

Trying to understand how the socialist system operated by looking only at the formal organisational structures would be highly misleading. It would be like attempting to understand how the market economy operates by reading orthodox 
economics text books. In the socialist economies informal networks played a key role in 'getting things done'. They were essential in compensating for chronic shortages of raw materials, spare parts and equipment. The pervasiveness of bargaining and interpretation of centrally planned systems as bargaining economies arises from reciprocal and asymmetrical relations in hierarchies. ${ }^{14}$

To cope with this problem in such a system it was necessary to have an institution: an informal network capable of negotiating relevant exchange proportions (how much will be done and what will be received in exchange). (See on this Kuznetsov, 1994). The role of informal networks was given attention by some Russian economists. For example, Gaidar (1990, chapter 2) argues that in the USSR investments were not directed to bottlenecks and to areas of the most acute shortages. Rather investment allocation was the function of the interest group and bargaining which was not directly linked to the shortages in the services it provided. Kuznetsov (1994) points out that what was most important was the support of all the parties on which the completion of the investment process depended: construction agencies, ministries providing equipment and other necessary inputs, and local authorities where the project was to be physically located (p. 11). The withdrawal of such support would bring investment projects to a halt no matter what the central planner's intentions. In such a situation things could be achieved only with the consent of all the parties involved. Similarly, in the case of Czechoslovakia, Klaus and Kezek (as quoted by Jeffries, 1993: 250) show that large, monopolistic enterprises used their superior information to 'dictate' plans to the central authorities. Mlcoh (1993, as quoted by Kenway, 1994), also discussing Czechoslovakia, argues that 'distortion of planning information is not done against the superior body (by providing incomplete

\footnotetext{
${ }^{14}$ For this approach in the analysis of socialist economies see Aven, 1992, and Chavance, 1995.
} 
information) but in agreement with it; the planning game is a co-operative game' (emphasis as in original, p.24).

Since formal contractual obligations were prone to failure industrial managers had to develop the ability to 'get things done'. Managers were faced with a diversity of technological and organisational challenges and the way to cope with these challenges was to establish their own social network. Most often the costs of establishing such networks were not trivial and this contributes to explaining the pervasive problems in 'introducing' (vnedrenyie) new technologies into production. Probably only in the case of large scale projects, in which several parties could see that it would be in their interests, did it make sense to incur the costs of the creation of informal networks.

This feature of the centrally planned system was noted long ago in the OECD (1969) study which stated that 'in some industries the smooth passage of innovation cannot be entirely explained in terms of special organisational arrangements or the direct intervention of the government at the highest levels as in the defence and aerospace industry'. Often organisational problems were overcome through the informal and apparently highly successful initiatives of individuals and organisations. On the technical side, informal compensatory mechanisms (barter) complemented the formalised function of the maintenance, tool, and machine building departments within the enterprises in order to avoid risks of shortages and reduce dependence on informal networks. Grabher (1997: 109) reports that 'in the late 1980s these departments for which the GDR authorities had invented the term Rationiliserungsmittelbau, provided roughly $25 \%$ of all investments in equipment and employed more than 70,000 workers (...)possessing an extraordinarily level of craft skills and "chaos qualification" (...), that is rich experience in the development of ad hoc solutions.' These, what Grabher (1997) terms, 'chaos related skills' were essential 
to achieving production targets. Whether they were those skills that can be easily employed in a market economy or whether they are basically irrelevant is an issue for discussion (see on this Pavitt, 1997).

\section{Emergent systems of innovation in post-socialism: micro, sectoral, national and regional determinants}

Section 2 highlights one conclusion which is of relevance for this section which looks at factors that determine the emergence of systems of innovation (SI) in the post-socialist period in CEE. By extending the understanding of SI as a network consisting of actors and their links, in which competencies are employed, it can be concluded that in the socialist economy it was the actors and not the links per se that were the main problem.

The central actor of SI - enterprise - was merely a production, not a business organisation, with 'dislocated' finance, marketing, R\&D and often engineering functions. The reconstruction of enterprises is the central issue in the reconstruction of SIs in CEECs.

While socialist links were constructed and managed by government authorities after socialism new links had to be constructed and managed by enterprises. Although enterprises are the central actors in systems of innovation they do not operate as isolated entities. Their activities are shaped by national, sectoral and regional factors. Equally, enterprises themselves upgrade national, regional and sectoral factors of growth and competitiveness. The proposition in this paper is that systems of innovation emerge as a result of a mutual interaction between micro-, sectoral-, national- and regionally-specific factors and determinants. In figure 3 presents a 
conceptual framework in graphic form which illustrates the main argument in this section.

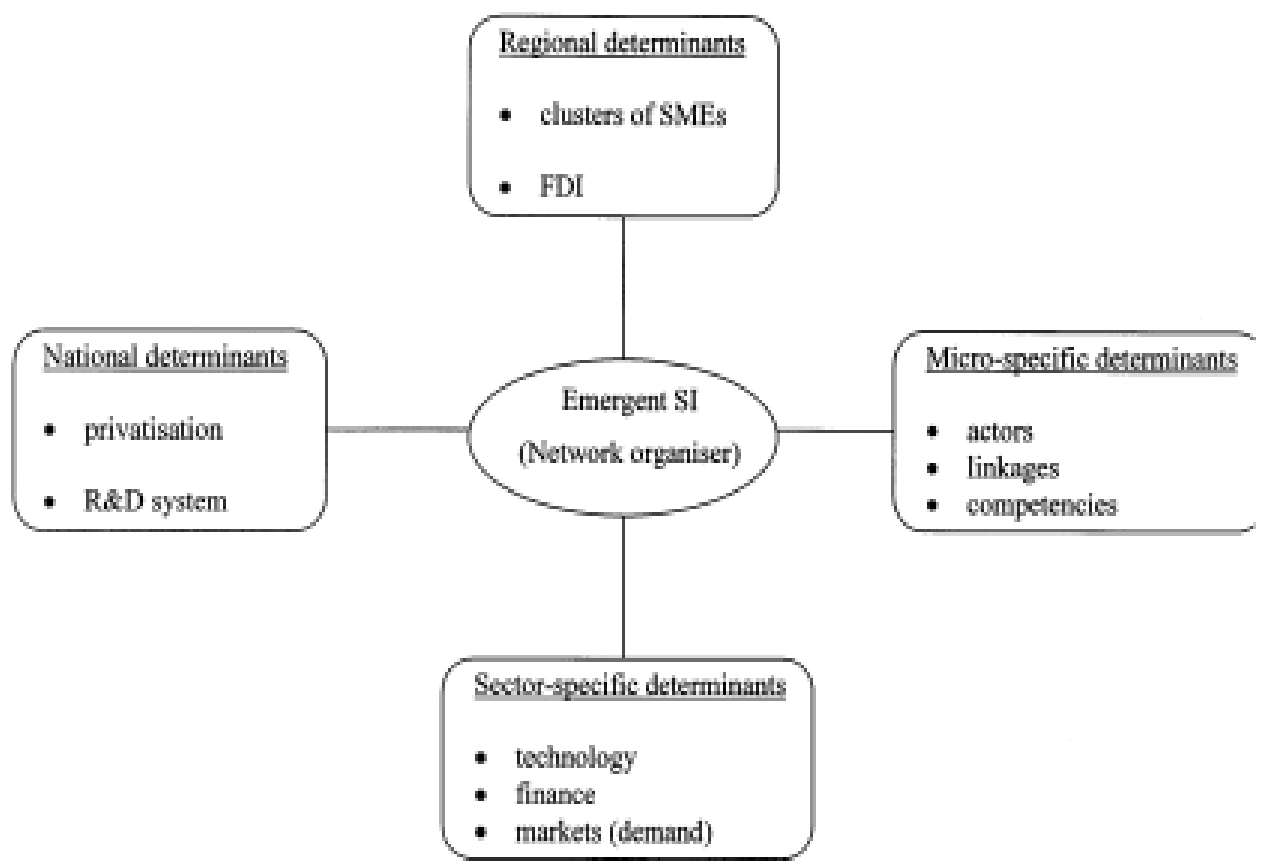

Fig. 3. Determinants of emergent systems of innovation in post-socialism.

The relative significance of each determinant varies with each case. The emergent systems of innovation are shaped through the interaction of all four levels. As a result, the basic feature of the model is indeterminacy of systems of innovation, i.e. system of innovation can emerge at any of the four levels depending on the strength of specific determinants. In this section this model is applied to the post-socialist CEE and each of the determinants of systems of innovation and their elements are examined.

3.1. Micro-specific determinants of systems of innovation: actors, linkages and competencies 
The emergence of SI in post-socialist economies evolves around the reconstruction of enterprises as the main actors, their links with other enterprises and public / private organisations, and competencies (functions) that are employed in the process of production and technical change (Alange et al, 1995). This section tries to show that in turbulent post-socialist environment these micro-level factors have the most immediate and the strongest effects on the (non)emergence of SI. As a result, it would be expected that the systems of innovation are still very much confined to individual enterprises or groupings of firms be they MNCs or domestic business groups.

\section{- Actors: enterprises and networks}

Post-socialist transformation is primarily change in the main actors of economic process. It is a change towards the reconstitution of enterprises as the main agents of industrial change as well as in the character of networks in which enterprises are embodied.

The transformation of SI in CEECs will be shaped by the way integration of functions at the firm level develop. As von Tunzelmann (1995: 10) points out 'by endogenously changing their circumstances through technological accumulation, firms may ultimately alter the national system itself'. New SI will be strongly shaped by the way enterprises develop their business functions. Enterprises which were previously only production units are developing previously 'dislocated' functions like finance, marketing, organisation and R\&D. For example, the degree to which the finance of enterprises depends on holding companies, banks, stock markets or on the state will strongly determine the profile of the national system of innovation and its dynamics. 
Because during socialism, the notion of the firm as a business entity was meaningless one would expect a large scale redefinition of enterprises and their boundaries. They are determined by the type of privatisation and can be modified through subsequent ownership changes. However, irrespective of the type of privatisation it seems that the common feature of enterprise organisations in CEECs is extensive cross-ownership between enterprises or between banks and investment funds over enterprises, or bank or enterprise-led financial-industrial groups.

An extensive presence of these mezzo institutions indicates, as argued by Grabher and Stark (1997), that the actual economic unit in post-socialism is not the isolated firm but the networks that link the firms and connect personnel across them. Networks are not only the units of restructuring but are also the agents of restructuring. These networks are country specific. They are groupings of enterprises linked either through inter-enterprise cross-ownership links (Hungary), through banks and investment funds (Czech R.) or through a mixture of these two (Russian financial - industrial groups).

\section{-Links or relationships}

In the socialist S\&T system, creation of technology was not linked to production and the economy was isolated from the world economy. The post-socialist departure from this initial state can be seen as a functional recombination or reconfiguration between enterprises and innovation infrastructure and between foreign and domestic enterprises (see Radosevic, 1998). For example, previously externalised engineering activities are becoming part of enterprises activities; in subcontracting relationships foreign enterprises are effectively substituting for the marketing function of domestic enterprises. However, this is not a simple recombination with unchanged dynamic 
properties; it is a restructuring in which functional recombination shapes the patterns and dynamics of technological accumulation. ${ }^{15}$ A good example of this 'recombinant innovation model' is the transformation of the Chinese electronics industry. ${ }^{16}$

Socialist enterprises had to internalise diverse functions because of the extremely poor quality of the local subcontracting services and materials suppliers. As Hare and Oakey (1993) show, the significant shortages and the poor quality of inputs to the production process explain in large part the behaviour patterns regarding input and output linkages. As there were no alternative suppliers in the centrally planned system, links were confined to a few enterprises and were one-directional (from R\&D institutes to user firms; from foreign suppliers to domestic actors). These links were around investment projects and not about continuous improvements (Bell, 1997). There were no feedback loops between the supplier of a good or service and the consumer.

Links now may become two directional. Learning inputs from users can be fed into the technology innovation process of producers. Although users are now playing an important role, for learning to occur a critical level of demand for technology by users is a precondition. At the moment, this demand exists only in a very few sectors. One good example is the demand from banks for IT which has led to the development of this particular domestic software segment (Bitzer, 1997). In opening up the economy, learning inputs from foreign partners through different forms of foreign direct investment, alliances and subcontracting are becoming essential. Foreign partners

\footnotetext{
${ }^{15} \mathrm{~A}$ phenomenon that recombination of existing competencies in economy may create much more innovation dynamics is conceptually developed by David and Foray (1994). They show that institutional arrangements exert strong influence on knowledge distribution and that innovation is developed through recombination of the existing knowledge, i.e. innovation is a function of knowledge distribution.

${ }^{16}$ See on this analysis by Shulin and Steinmueller, 1996.
} 
operate as the main source of technological innovation, especially organisational, leading to high productivity improvements in foreign investment enterprises. ${ }^{17}$

\section{-Functions and competencies}

The reconstitution of enterprises and the reconstitution of links with domestic and foreign partners bring significant transformation to competencies and a redistribution of competencies between enterprises and innovation infrastructure. A change in the techno-economic profile of enterprises is the change of focus from the mastery of production know-how to non-tangible and non-technological assets like management. This reconstitution of enterprises and their links in post-socialism has revealed:

- a lack of marketing skills, finance, organisation;

- a lack of product system integration capabilities;

- a lack of network building capabilities at firm level;

However, production capabilities, including in particular engineering and workers' skills, are often shown to be higher than might be expected.

As business press evidence shows, presently the biggest problem for foreign companies is to find network organisers at firm level and system integrators at product level. Companies that are able to integrate the system at product level (combining foreign with domestic solutions, customisation, etc.), and organise networks at firm level (manage domestic subcontractors) are in a much better position when entering into alliances. Those able to acquire strategic assets like

\footnotetext{
${ }^{17}$ For evidence on productivity levels see Hunya, 1996a,b.
} 
distribution systems and supplier networks will basically shape the industrial structure in the future.

In the early phases of post-socialist transformation, restructuring patterns are determined by the value of the 'localised' learning processes inherited from the closed economy in the new, open and capitalist environment and by the state of demand. A market value of inherited technological capabilities strongly influences the prospects for enterprise and knowledge base restructuring as well as determining the prospects for involvement of foreign strategic partners. One of complexities of the post-socialist transformation is that the immediate market value of many of the inherited competencies is low as either their outputs are not geared to users' needs or else significant further development is needed. This explains the rather mixed effects of commercialisation of, for example, Russian technologies developed within the defence complex (see on this Bernstein, 1997, and Sedaitis, 1997). Where products or capabilities on which these are based are of high quality and are user friendly they usually attract restructuring agents be they domestic entrepreneurs or foreign investors.

In summary, the reconstruction of enterprises, the extent of their linkages to other enterprises and organisations, and the profile of inherited firmcompetencies strongly determines the (non)emergence of SI in CEE. Table 4 summarises the results of several industry studies in five sectors in CEE and interprets their results through an actors, linkages, competencies framework. 
Table 4: Changing actors, linkages and competencies in central Europe

\begin{tabular}{|c|c|c|c|c|}
\hline & Dominant actors & $\begin{array}{l}\text { Production / technology } \\
\text { links }\end{array}$ & Competencies employed & Overall pattern \\
\hline $\begin{array}{l}\text { Computers } \\
\text { (Havas, 1998, } \\
\text { Kubielas, 1998, Bitzer, } \\
\text { 1997b) }\end{array}$ & $\begin{array}{l}\text { Electronic conglomerates and small } \\
\text { co-operatives in the ' } 80 \text { s have been } \\
\text { replaced by SMFs and foreign } \\
\text { investors }\end{array}$ & $\begin{array}{l}\text { Subcontracting and } \\
\text { foreign investment type } \\
\text { links }\end{array}$ & $\begin{array}{l}\text { Low (subcontracting) and } \\
\text { high end of competence } \\
\text { spectrum (design) }\end{array}$ & $\begin{array}{l}\text { Old networks wiped out. } \\
\text { Domestic PC assemblers } \\
\text { are strongly present. } \\
\text { Higher computer } \\
\text { segments are foreign led. }\end{array}$ \\
\hline $\begin{array}{l}\text { Software } \\
\text { (Bitzer, 1997, } \\
\text { Kubielas, 1998, } \\
\text { Bernstein, 1997) }\end{array}$ & $\begin{array}{l}\text { Software as only in house activity of } \\
\text { R\&D institutes and large } \\
\text { combinates is being transformed } \\
\text { into independent sector populated } \\
\text { by domestic SMEs. }\end{array}$ & $\begin{array}{l}\text { Strong links with } \\
\text { domestic users and } \\
\text { foreign suppliers through } \\
\text { alliances (ICAs)+ few } \\
\text { export niches houses }{ }^{18} \\
\end{array}$ & $\begin{array}{l}\text { Maintenance and } \\
\text { customisation and } \\
\text { emerging system } \\
\text { integration skills }\end{array}$ & $\begin{array}{l}\text { Newly emerging } \\
\text { innovation networks } \\
\text { based on alliances } \\
\text { between domestic and } \\
\text { foreign SW firms. }\end{array}$ \\
\hline $\begin{array}{l}\text { Telecom equipment } \\
\text { (Mueller, 1998, } \\
\text { Hirschhausen, 1996c, } \\
\text { Constantellou, 1997, } \\
\text { Kubielas, 1998) }\end{array}$ & $\begin{array}{l}\text { State run enterprises are now being } \\
\text { taken over by foreign owners }\end{array}$ & $\begin{array}{l}\text { Strong links with } \\
\text { domestic users and } \\
\text { foreign parent companies. }\end{array}$ & $\begin{array}{l}\text { Adaptation of generic } \\
\text { solutions to domestic } \\
\text { networks }\end{array}$ & $\begin{array}{l}\text { Domestic networks are } \\
\text { being replaced by foreign } \\
\text { network organisers. }\end{array}$ \\
\hline $\begin{array}{l}\text { Car assembly } \\
\text { (Havas, 1997) }\end{array}$ & $\begin{array}{l}\text { Vertically integrated combinates are } \\
\text { being replaced by foreign owned - } \\
\text { greyfield or greenfield - investors }\end{array}$ & $\begin{array}{l}\text { Integration into foreign } \\
\text { investors sourcing } \\
\text { networks at still low } \\
\text { levels of integration }\end{array}$ & $\begin{array}{l}\text { Production and } \\
\text { engineering } \\
\text { skills }\end{array}$ & $\begin{array}{l}\text { Domestic networks are } \\
\text { being replaced by foreign } \\
\text { network organiser }\end{array}$ \\
\hline $\begin{array}{l}\text { Shipbuilding } \\
\text { (Bitzer and von } \\
\text { Hirschhausen, 1997) }\end{array}$ & Domestically controlled shipyards & $\begin{array}{l}\text { Strong links with foreign } \\
\text { partners through alliances }\end{array}$ & $\begin{array}{l}\text { Process engineering and } \\
\text { design in low-end } \\
\text { segments }\end{array}$ & $\begin{array}{l}\text { Domestic network } \\
\text { organisers }\end{array}$ \\
\hline
\end{tabular}

ICA = international co-operative agreements

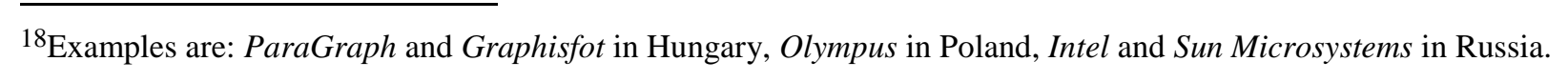


The outline of changes in these five industries indicates the significant extent to which changes have occurred in terms of actors, links and competencies employed. As a result, the main players are now foreign companies and hence links with them are essential for domestic enterprises. In the past, the essential link for innovation was that with domestic R\&D institutions, a link which is now being broken. However, the changes in actors, competencies and links are not strong in all sectors. Examples of the CEE steel industry (CERNA, 1996), the Romanian metallurgy sector (Bell, 1997) and Russian aviation industry (Vorobjev, 1996, Shaw, 1996) show that not much has changed in terms of links.

Changing actors, linkages, and competencies generates diversity in the sectoral patterns of innovation through an increased diversity of sources of technical change (users, foreign partners) as well as appropriability mechanisms (IPR, lead time, cumulated know-how, etc.). This diversity of sectoral patterns is not only the outcome of opening but also of the diversity of inherited competencies. ${ }^{19}$ The specificity of CEE is the variety of competencies or technology positions which domestic enterprises occupy in different international networks. ${ }^{20}$ For example, in the software sector three technologically different positions of the CEE producers can be found:

- adaptation of foreign proprietary software

- contracting software development, maintenance and translation to new languages $a$ la India

- development of proprietary software through sophisticated niche software exporters.

\footnotetext{
19 For evidence on several Russian sectors see Bernstein, 1997.

${ }^{20}$ For more evidence on this see Radosevic, 1997c.
} 
This diversity is not only an intra-sectoral feature but can even be found to be an intra-firm feature. Havas (1998) and Szalavetz (1997) cite the example of Videoton, the Hungarian electronic ex-combinate, that is integrated into international production networks in very diverse ways ranging from subcontracting in electronics in the manner of east Asia some years ago (Hobday, 1994), to carrying out of joint R\&D with foreign partners.

\subsection{Sectoral determinants of systems of innovation; markets, technology and}

finance

Sectors as organisational frameworks for innovation activities have lost the importance and meaning that they had previously in the socialist economy. Newly formed conglomerates and holdings are mainly inter-sectoral. ${ }^{21}$ However, sector specific determinants expressed through technology, finance and market requirements represent an important constraining or enabling factor in shaping innovation systems in CEECs.

In table 5 the basic patterns of restructuring in six industries in CEE are summarised by pointing to demand (market), finance and technology as the main structural determinants in this process. All six industry studies suggest that the market demand is essential for the restructuring process. In those sectors or subsectors where domestic demand is growing it is more likely that progress in industrial modernisation will take place. However, restructuring will not occur as a result of increased demand which

\footnotetext{
${ }^{21}$ Only in Russia the officially registered FIGs are organised along sectoral lines. However, informal FIGs are much more inter-sectoral. See several issues of Russian business journal 'Expert' on these groups.
} 
could be met by import. Sectoral studies suggest that the shape and pace of the restructuring process are also determined by technology and finance gaps. If both finance and technology gaps are small, as is the case in PC assembly, customized software and - partly - in the food processing industry, it might be expected that the domestic-led restructuring would take place. Indeed, these sectors are growing in all CEECs, including Russia. If, on the other hand, the technology gap and/or finance are a problem, then problems can be expected in modernisation. This may lead to significant country differences. In telecommunication services, where the gap in finance and technology is the greatest, this problem has been often resolved in CEE by the surrendering of control over the modernization process to foreign investors. Similar trends can be observed in car assembly. In shipbuilding, where the technology gap in low-end segments was not a major issue, domestic finance enabled successful domestic control of the modernization process in Poland (Bitzer, and von Hirschhausen, 1997). In higher-end computer segments (workstations and mainframes) where technology is highly proprietary, where domestic demand is not growing and where finance requirements are high the ex-socialist producers have closed down in all CEECs (Bitzer, 1998)). Moreover, in the face of weak domestic demand in the higher segments and a lack of competitive advantages for sourcing production in these segments, foreign investors have not yet entered on any large scale. It is only recently in Hungary that a spread of foreign investments in electronics can be seen.

The emphasis on market, technology and finance does not mean that these factors are the only determinants of the restructuring. For example, in PC assembly sector in all CEECs domestic producers have a strong presence but their market shares differ significantly. In the automobile industry we find that similar factor endowments in 
terms of markets, finance and technology have led to different modernization patterns even within one country. For example, in the cases of Skoda and Tatra in the Czech Republic. Whether similar structural situations will result in similar outcomes depends on micro-specific factors, including management capabilities, and on national factors, in particular political control of the privatization process. In all six industries market, technology and finance gaps are significant structural factors of modernisation. However, they alone cannot determine the final outcomes of modernization for a variety of other micro and macro factors. 
Table 5: Determinants of systems of innovation at sectoral level in CEECs: markets, finance and technology

\begin{tabular}{|c|c|c|c|c|c|c|}
\hline & Car industry & Shipbuilding & Food processing & Software & Telecoms & Computers \\
\hline $\begin{array}{l}\text { Markets } \\
\text { (demand) }\end{array}$ & $\begin{array}{l}\text { Growing domestic demand } \\
\text { Proximity to EU markets }\end{array}$ & $\begin{array}{l}\text { Large scale orders are } \\
\text { critical }\end{array}$ & $\begin{array}{l}\text { Growing domestic } \\
\text { demand for } \\
\text { differentiated } \\
\text { products; Problems in } \\
\text { accessing foreign } \\
\text { market }\end{array}$ & $\begin{array}{l}\text { Growing domestic } \\
\text { market; }\end{array}$ & $\begin{array}{l}\text { Growing domestic } \\
\text { market but with big } \\
\text { differences in terms of } \\
\text { effective investment } \\
\text { demand }\end{array}$ & $\begin{array}{l}\text { Growing domestic } \\
\text { demand for PCs; } \\
\text { Weak demand for } \\
\text { workstations and } \\
\text { mainframes }\end{array}$ \\
\hline Finance & Lacking finance & $\begin{array}{l}\text { Solving the issues of } \\
\text { debts and external } \\
\text { funding is critical; } \\
\text { Financial restructuring } \\
\text { required. }\end{array}$ & $\begin{array}{l}\text { Relatively low finance } \\
\text { requirements; } \\
\text { Possibility to raise } \\
\text { domestic finance. }\end{array}$ & $\begin{array}{l}\text { No large finance } \\
\text { required for } \\
\text { customized SW; } \\
\text { Finance as a problem } \\
\text { in complex projects } \\
\text { and standardized SW }\end{array}$ & $\begin{array}{l}\text { Large finance } \\
\text { requirement }\end{array}$ & $\begin{array}{l}\text { Low finance } \\
\text { requirements in PCs; } \\
\text { Large finance } \\
\text { requirements in higher } \\
\text { segments }\end{array}$ \\
\hline Technology & $\begin{array}{l}\text { Lacking product } \\
\text { engineering know-how; } \\
\text { Weak organisational } \\
\text { capabilities for } \\
\text { restructuring supplier } \\
\text { networks }\end{array}$ & $\begin{array}{l}\text { Easier access to } \\
\text { technology in low-end } \\
\text { segments; } \\
\text { ICA important for } \\
\text { accessing technology }\end{array}$ & $\begin{array}{l}\text { Technology is } \\
\text { accessible; Integration } \\
\text { of different } \\
\text { technologies requires } \\
\text { organisational } \\
\text { capabilities }\end{array}$ & $\begin{array}{l}\text { Technology accessible } \\
\text { through ICA; } \\
\text { Competitive } \\
\text { advantages of } \\
\text { domestic firms in } \\
\text { customized SW; } \\
\text { Technology gap in } \\
\text { standardized SW }\end{array}$ & $\begin{array}{l}\text { Huge technology gap } \\
\text { in telecom equipment }\end{array}$ & $\begin{array}{l}\text { Accessible technology } \\
\text { and components in PC } \\
\text { assembly; Huge } \\
\text { technology gap in } \\
\text { higher segments }\end{array}$ \\
\hline Overall pattern & $\begin{array}{l}\text { Lacking finance and } \\
\text { product engineering gap } \\
\text { accompanied by small } \\
\text { domestic markets leads to } \\
\text { restructuring by foreign } \\
\text { assemblers in central } \\
\text { Europe }\end{array}$ & $\begin{array}{l}\text { Given the available } \\
\text { external funding and } \\
\text { easier access to } \\
\text { technology the } \\
\text { restructuring process } \\
\text { depends on the large } \\
\text { scale orders - foreign } \\
\text { or domestic }\end{array}$ & $\begin{array}{l}\text { Lower finance gaps } \\
\text { and easier access to } \\
\text { technology allowed } \\
\text { domestic - led } \\
\text { restructuring which is } \\
\text { accompanied by } \\
\text { foreign-led } \\
\text { restructuring in } \\
\text { differentiated products }\end{array}$ & $\begin{array}{l}\text { Growing domestic } \\
\text { market, low finance } \\
\text { requirements and } \\
\text { access to technology } \\
\text { via ICAs enabled a } \\
\text { visible presence of } \\
\text { domestic firms in } \\
\text { customized SW }\end{array}$ & $\begin{array}{l}\text { Growing domestic } \\
\text { market but huge } \\
\text { finance and } \\
\text { technology gap led to } \\
\text { a strong presence of } \\
\text { foreign network } \\
\text { organisers }\end{array}$ & $\begin{array}{l}\text { Growing domestic } \\
\text { market, low finance } \\
\text { requirements and } \\
\text { access to components } \\
\text { from world market } \\
\text { enabled a visible } \\
\text { presence of domestic } \\
\text { PC assemblers }\end{array}$ \\
\hline
\end{tabular}

Note: ICA - international co-operative agreements; SW - software; Source: Based on Richet and Bourrasa (1998), Bitzer and Hirschhausen (1998), Charpiot-Michaud (1998), Bitzer (1998), Mueller (1998) and Bitzer (1998b). 


\subsection{National determinants of emergent systems of innovation}

The literature on national systems of innovation demonstrates the strong role of national factors in determining the basic features of the technology accumulation process (Freeman, 1987; Nelson and Rosenberg, 1992; Lundvall et al, 1992). However, as argued by Nelson (1997), it is a mistake to ask whether it is national factors or strong firms that create comparative advantage since 'in those cases where the national institutional environment, or legal structures, or specific policies, seem to have made a big difference, one also sees firms effectively taking advantage of the potential'. While firms take advantage of favourable national factors they themselves also upgrade national factors.

Post-socialist national differences do not arise only from differences in national factor endowments and factor prices but also, and perhaps more so, from national institutional differences. These are explicitly taken into account in the EBRD assessment of progress in the transition towards an open, market economy of the CEE countries (see EBRD, 1994, 1995, 1996). From a systems of innovation perspective a relevant question in this context is what are the main national determinants of actors, links and competencies, i.e. the micro-determinants of SI. It is obvious that national differences have been important in the past and that in the post-socialist environment they continue to be important. National differences are pronounced in terms of growth so that there is an increasing divide between CEECs, especially between central European economies and large economies of the former Soviet Union (see von Hirschhausen, 1996b). In the trade structure, the relative positions of different CEE countries are becoming increasingly divergent (see Landesmann and Burgstaller, 
1997, and Landesmann, 1997).22 From this it would logically follow that increasing diversity of NSI in CEEs would also be seen.

The NSI is a rather fuzzy concept with problems in terms of its boundaries and building blocks (Radosevic, 1998b). Here, we will distinguish between 'narrow' and 'broad' NSI. By 'narrow' NSI we mean the R\&D system and other institutions involved in explicit innovation activities. By 'broad' NSI we mean all other institutions which indirectly affect generation of technical change and diffusion of innovation. 'Narrow' and 'broad' national systems of innovation are interrelated but 'narrow' NSI also has a certain degree of autonomy (Freeman, 1999). This is important for understanding why changes in 'narrow' NSI are not immediately reflected in 'broad' NSI and then in growth and recovery.

The 'narrow' NSI in CEE is undergoing a large-scale functional, organisational and funding restructuring (see Meske et al, 1998 for evidence). From being the main source of R\&D and innovation, extra-mural R\&D organisations - especially industrial institutes - are transforming themselves into either R\&D companies trying to meet diverse pockets of new $R \& D$ and non-R\&D demand, or more often are turning themselves into non-R\&D service organisations which form the core of the emerging business service sector in CEECs. The intensive intra-organisational restructuring of industrial and academic institutes is not followed by equally intensive interorganisational restructuring. The weak links between academy, universities, industrial institutes and enterprises from the past remain. Industrial institutes have not been integrated with industrial enterprises. Enterprises which are strapped for cash and long-term finance, and are facing tough foreign markets are not able to generate

\footnotetext{
${ }^{22}$ For analysis in terms of institutional differences and inputs in R\&D across CEECs see Radosevic and Auriol, 1998.
} 
demand for more upstream activities like R\&D. In such a situation $R \& D$ is perceived as a liability rather than as an asset.

What we find today in CEE are fragments of the old R\&D systems which are trying to adjust through a set of diverse survival strategies and new pockets of innovation activities. ${ }^{23}$ Industrial institutes are being left on their own and are undergoing a slow process of conversion into different new forms (service firms, industrial enterprises). Academies of Science institutes, attracted by government funding as the only stable source, are shifting towards basic research or are diversifying sources of income to non-R\&D activities. Universities are trying to build a new position based on the stability which comes from teaching but are also attempting to reorient their activities towards research. In-house R\&D departments, where they exist, are oriented towards their own needs and are trying to build-up links with foreign sources of innovation. Domestic subsidiaries of foreign MNCs are entirely oriented towards the parent company in all the most important functions, including $R \& D$, finance and marketing. Overall, the NSIs in CEE are fragmented and each institutional sector and organisation is searching for its own optimum unrelated to others. Intra-organisational restructuring by splitting institutes into smaller organisations or through the creation of spin-off firms attached to institutes dominates over inter-organisational restructuring involving several organisations from different sectors like industry, university, academy or industrial institutes.

Is this an indication that the NSI in CEE have not been formed? In terms of organisational structure all CEECs do have fully developed S\&T systems. However, this does not mean that they have also developed national innovation systems. Organisations which nominally belong to an R\&D sector by themselves do not form a

\footnotetext{
${ }^{23}$ For an extensive account of changes in R\&D systems in CEE see Meske et al (1998), Knell, Hutschenreiter and Radosevic (1999) and Radosevic (1999).
} 
system of innovations. Extensive organisational superstructure and R\&D capacities should not be confused with the notion of innovation system, which implies knowledge links and knowledge flows in the innovation process as a collective activity. Only when organisations are linked to each other on a national scale in the innovation process can we talk about NSI. If we look at S\&T in CEEs from this perspective then their national systems of innovation are still very fragmented and rudimentary. This fragmentation comes primarily from the weakness in the reconstitution of enterprises as the main network organiser of innovation processes.

National differences in the reconstitution of enterprises are mainly determined by privatisation patterns. Nationally specific privatisation patterns strongly influence patterns of network restructuring. In eastern Germany the individual Treunhandanstalt-led privatisation abolished the old production networks; in the Czech R and Russia mass privatisation led to only a gradual transformation of production networks, while individual privatisation in Hungary led to the break-up of networks through the presence of strong foreign investors or to their restructuring through extensive cross-ownership. Delays in privatisation in Romania have frozen inter-enterprise links leading to a reduction in the scale of enterprises and institutes. As shown by Bell (1997) in the case of the metallurgy sector the whole system is frozen but operates on a smaller scale.

The more significant the changes due to privatisation the stronger is the shift in enterprise boundaries and the more significant the changes in links and competencies. The fewer the changes resulting from privatisation the less is the deconcentration in industry and hence reduction in demand for R\&D. In the Czech R there is a very low deconcentration of enterprise size. The number of enterprises with over 2.5000 employees in 1990 was 645, in 1993 it was 508, with total employment in this group 
being 645,000 in 1992 and 508,000 in 1993 (Statistical yearbooks CSFR, 1991 and 1994 as quoted by Mueller, 1997, p. 25). This is in sharp contrast with eastern

Germany where deconcentration of industry was extremely strong which led to almost the disappearance of demand for R\&D (see Meske, 1997). In summary, different types of privatisation produce different structures of demand for R\&D and technology given that other factors remain unchanged.

As Freeman (1999) points out, the crucial weakness of the NSI in socialism was the failure to develop R\&D at the enterprise level. The building of the future NSI will depend on how this process will progress in different countries. The increasing divergence in terms of growth and restructuring between 'western' and 'eastern' CEECs suggests that the reconstitution of enterprises as the main actors in the innovation process may lead to a faster emergence of NSI in central Europe than in CIS, Romania and Bulgaria. The reason for this is partly historical as these countries have inherited from the socialist period a larger share of enterprises with in-house R\&D activities. As a result of this 'deviation' from the Soviet R\&D model 'in-house' $R \& D$ in some large enterprises has survived the period of drastic cuts in $R \& D$ activities at the outset of transition.

The new NSI will be formed by the way enterprises embodying innovation activities. The building of dynamic innovation systems depends on the establishment of framework conditions concerning privatisation, finance, legal protection, communication infrastructure. These elements of 'broad' NSI strongly influence innovation activities of enterprises. In the transition period they are actually more decisive for the innovative activities of enterprises than 'narrow' NSI.

For the time being, it is not yet clear what national systems of innovation are emerging in the CEECs. These systems are still a long way from being formed and it 
would be more appropriate to search first for signs of the emergence of sectoral innovation systems. Sectoral innovation systems are groupings of enterprises and their related networks of public and private institutions which are involved in the development, diffusion and utilisation of innovation. These systems will strongly shape the character of NSIs in CEE. Based on the current patterns of production networks in CEECs it seems that NSI will be very heterogeneous. In countries, like Hungary, NSI may be based more on foreign enterprises. In Russia, they may be formed around large domestic industrial groups. In countries like Estonia they may be formed around small enterprises. In some CEE countries NSI could be dual in character with sub-sectors of small and large firms being unrelated to each other, or with weak links between domestic and foreign firms. Alternatively, NSIs could be formed around one or two sectors where the innovation process is developed on a collective basis while in the rest of the economy the innovation links are very weak. For the time being, the innovation activities are the strongest in links with foreign enterprises. This suggests that in most small CEECs their NSIs could be shaped by the way they become integrated into international production and innovation networks. In general, NSIs in CEE will be shaped by the way enterprises reconstruct their links and embody innovation but also by the way the state regulates interaction with MNCs. The foreign enterprises are for the time being those that are strongly shaping the nature of production networks in almost all CEECs. Also, the innovation activities are emerging in links with foreign enterprises through different forms of alliances and subcontracting. However, the interaction between domestic and foreign capital is mediated by the state. So, political or control dimension of the process of technical modernisation are important in understanding the nature of the emerging NSIs in CEE. 


\subsection{Regional determinants of emergent systems of innovation}

While national factors did, and still do, play an important role in the national technology accumulation process in the CEE, the same cannot be said for regions. Proximity was not an asset under socialism. A rare empirical test of this proposition is developed by Hare and Oakey (1993) who show the centralised pattern of service provision in the machine tool industry in Hungary with companies strongly concentrated around the Budapest area. Respondents from the plants located near or in Budapest experienced greater problems with local service agents than their peripheral counterparts. The plants with the best access to service agents were also those that encountered the greatest service problems. This seemingly paradoxical outcome is logical in conditions where the availability of a service outlet with an inferior level of service provision causes more difficulties than the complete absence of such provision. When no local servicing facilities exist, this leads to greater self-reliance which ensures better maintenance and repair of machines.

The pre-socialist intra-regional forward and backward linkages were severed and superseded by inter-regional linkages within the branch or within the combinates. The individual plants of the combinates had no economic relations with the region in which they were located (Grabher, 1997, for eastern Germany) but they had strong social linkages with the region. Regions were deprived of agglomeration economies, that is, economies that arise from a diversified regional economic structure and that are essential for the long-term adaptability of regions (Grabher, 1997, p. 111).

In the case of regions, innovation links were almost non-existent and are now to be developed either between large and SMEs or between SMEs themselves. The link 
between R\&D and industry at a local level has yet to be established. For example, an innovation survey of the Gdansk region in Poland confirms that there is still a strong detachment from the region and the use of local $R \& D$ institutions as a source of technology (see Kalinowski and Sobczak, 1996). From currently being a liability it will be some time before these regions become an asset in the process of technology accumulation. ${ }^{24}$

The economic role of regions in CEE will differ significantly with the type of region. To make a diversity of the CEE situation simpler a very rough but illustrative grouping of regions might serve.

1. Capital towns and regional centres with a diversified economic structure and developed infrastructure. Examples of the latter group would be Gyor (Hungary), Varna (Bulgaria), and Plzen (Czech R).

2. Regions with a more diversified economic structure where lower industry share meant that they started with less structural problems. This was then followed by either intensive new firm formation and foreign investments. Examples are Poznan province in Poland and Csongrad (Szeged) in Hungary.

3. Monostructural regions where a single sector heritage (defence; agriculture; heavy industry) makes restructuring based entirely on endogenous resources very difficult and in some cases almost impossible. Examples of these cases abound in Russia. One good example of this type is the Perm region in Russia a centre of defence industry (see Cronberg, 1994). An example of the old industrial centre in Hungary is the BAZ

\footnotetext{
${ }^{24}$ For discussion on policy aspects of this process see Radosevic, $1999 \mathrm{~b}$.
} 
region (see Lorenzen, 1995). However, similar cases can be found even in very small CEE countries, like Slovenia, with its old industrial centre of Maribor.

If one was to approach to regional restructuring by taking into account only the state of tangible regional endowments of labour, capital and natural resources it could be hypothesised that difficulties in regional restructuring would follow in ascending order from 1 to 3 . However, more detailed regional situations within individual countries would show that this is probably not the case. An analysis of Russian regions by Hanson (1995) clearly shows the limitations of such an approach and reveals the much more complex dynamics of regional restructuring. The example of Nizhnii Novgorod, a heavy defence-industry dependent region but a front-runner in reforms in Russia, illustrates this point very well. Any comparative advantage or disadvantage for regional restructuring is conditional upon the existence of knowledge networks and network organisers.

One of the major difficulties in regional transformation in CEE besides capital, infrastructure and knowledge deficiencies is the enormous co-ordination problem. For example, in the defence-based regions of Russia traditional links between defence companies and defence ministries have collapsed and new links between the regional administration and enterprises, and among the enterprises themselves should emerge in the regional context. This transformation is strongly influenced by national factors which, similar to the EU less developed regions (see EC, 1995), play a major role in determining inter-regional disparities. For example, stability in the growth of SMEs cannot be achieved by activities at the local level if they are to become suppliers of the big companies who are in difficulty. 
Despite the great variety of country specific regional situations there are some common features to regional transformation in CEE. These are in the break up of previously vertical channels of communication and economic management, and in the lack of horizontal information flows as a result of their socialist heritage. This lack of horizontal communication channels is being addressed already in some central European countries through the building up of a still very weak layer of new agencies which should assist regional enterprises. However, such organisations are not strong enough to make any significant changes to a structurally very difficult situation. This process is also helped by newly emerging enterprise forms like holding companies, financial - industrial groups, and new private conglomerates which are primarily horizontal structures which strengthen horizontal communication and form new input - output linkages. Foreign investors, for example the Suzuki supplier system in Hungary, are also encouraging relationships between the now fragmented large enterprises and SMEs.

However, despite these trends the region as a determinant of the emergence of SI in CEE is still very weak. The relative share of regions with a diversified economic structure in CEEC seems to be lower than in the EU. With the proliferation of medium and small sized companies this is now changing. However, there are signs of clustering among SMEs or between domestic and foreign firms.

\section{Production networks and the network organiser}

Section 3 analysed the four determinants of the emergent systems of innovation in CEECs. By themselves, they are only a conditional advantage which requires 
network organisers to be turned into a real advantages. The question is who are the potential network organisers that could undertake the task of organising systems of innovation or contribute to a transformation of the emerging production networks into innovation networks? This section discusses the role of each potential network organiser (foreign firms, domestic independent firms, domestic business groups, design institutes, etc.).

Post-socialist transformation is a process of radical change in ownership and factor prices accompanied by simultaneous large scale institutional restructuring. It is also a process of recombination of the previous institutional links and integration of previously dislocated business functions into enterprises. The scope of these changes and space for possible future recombinations are constrained by the past features of the system or, in other words, much institutional change is path-dependent.

A progress in 'transition' is usually seen as the process which contains only elements of change. In accordance with this, the EBRD measures progress in transition by focusing on changes towards the model of an open market economy (see EBRD, 1994; 1995; 1996). Two processes along these lines are new enterprise creation and unbundling of former socialist industrial combinates into stand-alone enterprises which should grow through generic expansion. However, together with the elements of change are found elements of recombination and path dependency. These are cases of new, durable inter-enterprise networks (e.g. post socialist holding companies, financial-industrial groups) and transformation of the previous branch administrations into enterprise (for example, telecom operators or, in the energy sector, the case of Russian Gazprom, see Kryukov and Moe, 1997). They indicate that the discontinuity of transition from plan to market is not as large as is commonly believed. 
Network restructuring is strongly dependent on the (non)existence of a network organiser. In the core of this is the problem of co-ordination and complexity of production networks. For example, it is mainly the simple production networks, i.e. woodworking, the garment industry, or commodities, that are re-orienting themselves relatively easily to world markets. In foreign trade this shift is present through the strong rise of labour-intensive, supplier dominated and commodities based sectors (see Landesmann, 1997; Guerrieri, 1999; Guerrieri, 1999b; Kubielas, 1999; Rosati, 1994). ${ }^{25}$ In the case of complex production networks, like those in the machinery sector, where inputs come from several enterprises and where payments per unit are much higher, these networks are deteriorating due to cash flow problems. Particularly in countries of the former Soviet Union they survive often only through barter. In the case of knowledge-intensive industries, like electronics or pharmaceuticals, once effective demand is identified, the accumulated skills of engineers and $R \& D$ could be more easily deployed in a new context than is the case with the complex engineering and capital based sectors. ${ }^{26}$

The argument here is that the prospects for rebuilding the economies of the CEE are not only conditioned by (dis)economies in production but also can result from the inability of actors in production networks to self-organise due to institutional uncertainty and co-ordination failures which hinder the selforganisation of industry. ${ }^{27}$ This process results in the emergence or non-

\footnotetext{
${ }^{25}$ For evidence in the case of Baltic economies see Radosevic, $1997 \mathrm{~b}$.

${ }^{26}$ For policy aspects of different types of production networks see Radosevic, 1994.

${ }^{27}$ The difficulty with the empirical testing of this argument is that in real life self-organisation ability may not be the only constraint; the state of demand, domestic and foreign may also be an influence. Also, strong import competition or export restrictions from EU in 'sensitive sectors' like agriculture may hinder self-organisation of industry.
} 
emergence of network organisers - organisations that act as promoters of trade, production and/or innovation linkages.

The ability of techno-economic networks to self-organise, probably with other factors unchanged, is inversely proportional to their production and organisational complexity. In addition, drastic currency devaluation and changes in relative prices resulting from liberalisation, favour primary or resource based production over industrial goods, with the latter being, on average, more complex than the former. The increased import content of exports is shifting these economies, at least temporarily, towards assembly-type specializations with low value-added (Guerrieri, 1999; Landesmann, 1997; Kubielas, 1999; Schmidt, 1998). As a result, engineering, and industries with extensive supplier networks, suffer the most vis-à-vis resource or labour intensive production activities which are usually confined to one enterprise with rudimentary marketing requirements.

However, it would be a mistake to argue that patterns of post-socialist industrial restructuring and the survival of their SI are only determined by the degree of complexity or simplicity of techno-economic networks. To back up this statement would require far more empirical research. ${ }^{28}$ Nevertheless, a valid argument may be that systems of innovation in post-socialism will be determined by the (non)existence of a network organiser. The more simple the production networks and the higher the quality of production the easier it is to turn around such enterprises and thus it is more likely that a network organiser will emerge. The more complex the production and the lower the underlying technological level the more difficult it will be to attract

\footnotetext{
${ }^{28}$ Elsewhere (Radosevic, 1997b) I tried to show in the case of Baltic states that meso variables (sectoral market and technological characteristics; privatisation context) in interaction with micro (top management behaviour; strategic partners) and macro factors (macroeconomic variables) ultimately shape the prospects for the development of organisational capabilities and enterprise growth in postsocialism.
} 
investors to invest in the reconstruction of such networks as the offer of market access will be insufficient.

\subsection{Who is a potential network organiser?}

Who is likely to be a network organiser in the post-socialist context? One focal point of any new network should be a user firm. Limited and unsystematic evidence shows that there is a wide diversity of network organisers. Network organisers are any actors with the necessary capability and resources - a user or supplier firm, a bank, a holding company or a financial - industrial group, a foreign trade organisation, a design institute, a foreign firm or, in some cases, even the state. However, given the management, finance and technology gaps described in Section 3 it is foreign companies that for the time being seem to be the most active network organisers in CEE.

Foreign firms Post-socialism creates opportunities for foreign firms to act for the first time in this region as organisers of domestic supply or distribution networks. In countries where foreign investments are relatively large, such as Hungary, or in sectors where foreign presence is relatively strong (telecoms, car assembly) this opportunity is being fully exploited. For example, telecom equipment production in CEECs is now dominated by foreign companies that basically shape domestic supplier networks. Also, foreign car producers are transferring their supplier networks into the region (for example, Fiat, VW, Daewoo, GM, Audi) creating in that way a nucleus of local systems of innovation. Large MNCs like $A B B$ have managed to set up a new supply network which involves almost all CEECs and some of their subsidiaries, such 
as Zamech, Poland, are plugged into $A B B$ design network (Barham and Heimer, 1998). However, foreign investors do not necessarily increase networking in the domestic economy. Empirical research in the case of Poland shows that while the internal effects of foreign investments on domestic firms have been marked, 'spillovers and leakages are notable by their absence' (see Hardy, 1997). As Grabher (1997) shows in the case of eastern Germany only some business strategies employed in the region actually integrate the domestic industry (for example the food and construction sector) and develop regionally responsive strategies. Other strategies require immobilisation of regional networks or local linkages which reinforces the fragmentation of the local economy. This may be countered only to some extent by government policy which in sectors like telecom equipment, may require local content. ${ }^{29}$ For the time being the spread of global production and distribution networks across CEECs can be seen. However, this should not be equated with technological networks or systems of innovation. These are only partly overlapping and it remains to be explored to what extent these production networks embody the transfer of innovation and exchange of new technological knowledge. When and how foreign led production networks in CEE get transformed into technology networks is an issue which remains to be explored.

Individual domestic enterprises It is argued that a possible network organiser in post--socialist CEECs can be any organisation with network organisational capabilities and resources. Individual enterprises that grow through generic expansion, or by mergers and acquisitions, are also potential network organisers or focal points of emerging sectoral systems of innovation. Fast growing private companies in sectors

${ }^{29}$ For the case of Hungary in this respect see Toth (1994). 
like software which, based on foreign solutions, build interfaces and adaptive solutions, are good examples (Kubielas, 1998). It is a matter for further empirical research to discover to what extent, by endogenously changing their circumstances through technology accumulation, firms are altering domestic sectoral systems of innovation.

In the case of very large companies that dominate national sectors their strategic behaviour strongly shapes not only the sectoral but also the national systems of innovation. ${ }^{30}$ For example, the behaviour of 'Skoda', Plzen, or the Polish corporation, 'Elektrim', basically shapes sectoral system of innovation in power equipment and related industries in these countries. The impact of the behaviour of 'Gazprom', the Russian gas producer, that is organised as a single joint-stock company and represents $10 \%$ of Russian GDP, reaches beyond the Russian gas sector into several related industries (Krykov and More, 1996).

Again, very little is known about the technology behaviour of these companies. Their strategy of acquisitions and divestitures does not necessarily reveal their role in innovation and technology acquisition.

Domestic business groups Domestic business groups are becoming increasingly important network organisers in the CEE. Similar to NICs (see Amsden and Hikino, 1994) the emerging capitalism of CEE may be characterised by the strong presence of business and industrial groups or generally large conglomerates. ${ }^{31}$ As pointed out earlier in this paper, their emergence in CEECs is the result of privatisation. However, I believe that, like the situation in NICs, there are developmental factors that explain their emergence, for instance, scarcity of organisational capital or undeveloped

\footnotetext{
30 For the role of large companies in national systems of innovation see Pavitt and Patel, 1995.

${ }^{31}$ For a broader discussion on the role of business groups in modern economies see Granovetter, 1995.
} 
financial markets. A phenomenon of CEECs' mezzo level groups has been analysed more systematically in the cases of Hungary (Stark, 1997) and the Czech R (McDermott, 1997). In the CEE environment the most controversial role in this respect is that of privatisation funds acting as the intermediary between owners and enterprises, and their capacity to deliver long-term finance. ${ }^{32}$ This will determine whether they will be purely a transitional form between inter-enterprises holdings and bank-enterprise groupings as final forms.

Here only a brief description is given of financial industrial groups (FIGs) which are the newly emerging organisational form characteristic of Russia (see Freinkman, 1995; Gorbatova, 1995; Prokop, 1995; Starodubravskaya, 1995). FIGs are new market-driven forms of preserving the old networks (path dependency feature) and they act as a mechanism for mobilising investments and establishing or saving production links (INIOR, 1996). Their emergence dates back to the 1992 corporatization and the mass privatisation that followed. Nearly all of the existing groups have been created in the process of privatisation and formation of securities market. As argued by Karlova (1996) the following methods were used:

- large industrial enterprise established their own banks;

- concerns and other associations were established on the basis of former state management structures (branch ministries) with further diversification of their activities;

- large regional industrial holdings were formed;

- bank and investment funds acquired shares of industrial enterprises.

\footnotetext{
${ }^{32}$ For a discussion on this in the case of Czech R see Kenway, 1994.
} 
However, specific to Russia some FIGs are initiated and supported by the state and are seen as important tools of industrial policy (Karlova, 1996). The 35 registered FIGs in Russia have 457 firms, 87 credit institutions, 2.5mn employment and their turnover is $10 \%$ of Russian GDP (Karlova, 1996, p 19). Most registered financial industrial groups in Russia are sectorally based which may alleviate the problem of scarce organisational capital. Further motives for FIGs are that they ease the liquidity problems of individual enterprises while banks ensure closer contact with new customers offering them circulation capital and, for the time being, only short-term loans. FIGs are also lowering the credit risk for external lenders. Holding companies could not solve the problem of finance as they are only associations of production enterprises without banks in the group.

The main advantages of groups are that:

- group costs are lower as a result of economies of scale, scope and vertical/horizontal (financial) integration;

- companies have access to low-rate long-term financing and reliable banks will be more active in longer-term investment than those outside FIGs (INIOR, 1996).

One problem associated with FIGs is their possible influence on the State ('State capture'). There is a danger that groups will not contribute economically and instead will distort competition by increasing barriers to entry, will monopolise markets, and will become rent seekers. It is very likely that once the state is captured, the long-term agenda for growth and restructuring gets squeezed by rent-seeking. This puts forward important issues such as the political economy of government - business relationships. 
Design institutes Under the former system the knowledge in design institutes was, in principle, greater than in enterprises. Since knowledge in enterprises is generally poor, we find cases, in Russia in particular, whereby design centres compensate for this (Alange et al, 1995) or become the main source of technical change and organisation of a network (Vorobjev, 1996; Shaw, 1996). As Alange et al (1995) show in the case of the machine tools sector, for the time being the design institute:

- acts as a system integrator, by fulfilling the engineering function which is still undeveloped in enterprises;

- compensates for the poor capabilities of the engineering function of enterprises;

- functions as a bridge between academia and industry. Also, Vorobjev (1995), in the case of the Russian aviation industry, argues that this network is led by a few leading design institutes.

Other actors Foreign trade organisations (FTOs) are one of actors that can reorganise production networks. Their position emanates from their thorough knowledge of domestic and foreign markets. Banks can also take on the role of network organisers by turning around companies and then selling them on. This process is still rare but is likely to be ongoing as margins from financial operations shrink and banks turn to the real economy. In some cases the State is taking on the role of network organiser in an attempt to create a national cluster (for example, in the Polish petrochemical industry).

To summarise, the diversity of possible network organisers that are likely to operate as central institutions in emerging systems of innovation in CEE has been highlighted Although it is not yet possible to provide sufficient systematic evidence of this I 
would argue that foreign firms have gone the farthest as network organisers. The cases of several industrial sectors in CEECs suggest the dominant role of foreign enterprises as network organisers. However, it does not follow from this that they will automatically play a major role in domestic national systems of innovation.

Production networks are not identical to technological networks and an important issues for CEECs is to what extent foreign firms will be embedded into the domestic economy. It can also be expected that domestic business groups will play an equally important role once the ownership structure becomes stabilised.

At a more general level, the emergence of new patterns of production and innovation links can be seen. Knowledge flows between different branches, between foreign sellers and domestic users, and between users and R\&D become possible. For the first time knowledge links may be between users (producing company) and design institutes. In some, though still rare cases, this leads to institutes being taken over by the company.

The market economy does not necessarily bring a strengthening of all innovation links compared with socialism. In principle, unlike the case of design institutes, the link between R\&D institutes and domestic user firms has weakened as a result of the R\&D institute becoming detached from industry due to lack of industry funding. Similarly, links between R\&D and design institutes have weakened (see Bell, 1997). The strongest links are with foreign partners. While this seems obvious in the case of FDI it is not so in the case of alliances. Here a diversity of links in terms of dependence/interdependency and in terms of market and production/technology focus can be found.$^{33}$ In subcontracting relationships such links often have features of dependence.

${ }^{33}$ For a discussion on alliances in CEECs see Radosevic (1999c, 1999d). 
In conclusion, in post-socialism new patterns of links between enterprises, buyers, sellers, and foreign partners are proliferating. While patterns of innovation are becoming more sector specific and, in that respect, more diverse the rise of mezzo industrial groups and foreign firms as important network organisers indicates the possibility of widespread cross-sectoral knowledge links.

\section{Conclusions}

1. The paper is based on the proposition derived from systems of innovation literature that catching up and growth of the CEECs is closely related to the emergence of systems of innovation be they inter-firm, sectoral, regional, national or global.

2. The socialist period was interpreted here through a systems of innovation perspective. The proposition was developed that the post-socialist economies are characterised by the transformation of a single standalone $S \& T$ system into a diverse array of systems of innovation. The main problem under socialism were not links per $s e$ but the inability of firms to embody innovation and to act as a network organiser. Instead, network organisers were ministries and branch R\&D institutes. This led to unrelated flows of production, market and technology knowledge and finance which resulted in a slow pace of innovation and weak structural change.

3. This paper analysed micro, sectoral, national and regional determinants of systems of innovation. Although in CEECs one still cannot talk of developed systems of innovation there are several determinants and processes which work towards their emergence. The conclusion is that the systems of innovation in CEECs are emerging 
through the interaction of micro-, sector-, national- and regionally- specific factors. This explains why the boundaries of systems of innovation are indeterminate as suggested by the recent literature on systems of innovation, i.e. SI can be at firm level, national, sectoral or regional (see Edquist, 1997). The indeterminacy comes from the mutual influence of each determinant in generating systems of innovation.

4. Systems of innovation in the post-socialist period in CEE are primarily driven by micro, and sectoral determinants. Innovation activities are still very much confined to individual enterprises or groupings of enterprises through parent companies (MNCs, domestic business groups). The patterns of innovation have become sector specific, i.e. they reflect the nature of technological regime in the industry given the market, technology and finance gaps of CEE producers.

The organisation of innovation activities which would reflect sectoral specificities was suppressed during the socialist period. Patterns of innovation in terms of appropriability and organisation were highly uniform across the entire industrial spectrum. In the post-socialist context there is an increasing diversity of sources of technical change as well as appropriability mechanisms. The innovation patterns of individual enterprises reflect a diversity of patterns of innovation typical for individual sector.

It is not yet possible to talk about national or regional systems of innovation in the CEECs. The only emerging systems of innovation seem to be those around foreign firms, and possibly around domestic business groups. A still turbulent process of industrial transformation does not allow national or regional responses to be articulated in a way that would lead to national or regional systems of innovation. Systems of innovation are in the process of articulation through a period of intensive 
trial and error by enterprises, governments and foreign partners. This is especially valid for growing central European economies.

5. The process of selection and development of network organisers is at the core of the emergent SI. In principle, these could be any of the organisations involved in the collective process of innovation creation and diffusion. However, the actual process is the result of a complex interaction of nationally specific factors, opportunities to recombine the existing competencies and link them to world production networks as well as the degree of change in factor and product markets.

So far, foreign enterprises have been the main organisers of production networks. Their inherent advantages in terms of access to finance, control over technology and organisational capabilities give them first mover advantages which domestically controlled firms are not able to match. However, domestic independent enterprises and business groups are now beginning to act as network organisers. In Russia, where national institutional specificities and historical heritage are different domestic network organisers are much more frequently found. This is the result of different patterns of privatization and political control of modernization process. In addition, developmental and economic factors also contribute to an increasing role by domestic business groups. Some of these may be common to the explanations of industrial groups in other latecomer economies (see Amsden and Hikino, 1994).

6. Elsewhere, the intensive process of reconstruction of production networks, which are focused around business groups, has been analysed at great length (see Grabher and Stark, 1997). However, the concern here is with innovation networks or the prospects for the emergence of different innovation networks which are not identical 
to production networks. Grabher and Stark (1997) analyse networks based on ownership and informal links but not on innovation and technology links. For example, a standalone company may have intensive knowledge links with other enterprises and yet not be linked through diverse informal or ownership links. These cases occur when enterprises have chosen to alienate themselves from any networks and to be free from any implicit and explicit obligations. ${ }^{34}$ While their analysis may describe very well the morphology of new ownership and production networks it does not explain the underlying factors of growth and the prospects for the growth of such networks. The inquiry is extremely useful but is not sufficient for a complete understanding of the innovation properties of new ownership and production networks.

7. The current modes and levels of integration of CEECs into international production networks may not by themselves ensure their growth and recovery. The current pattern of industrial upgrading, which is most often led by foreign enterprises, may reach its limits unless followed by domestically generated innovation activities. There are limits to which the lack of domestic in-house R\&D could be compensated for by extra-mural R\&D system or foreign R\&D. The weaknesses in 'narrow' NSI will become visible through weak in-house $R \& D$, weak university - industry links, and a lack of technological co-operation among enterprises. In order to grow these economies will have to generate their own innovation dynamics which can

\footnotetext{
${ }^{34}$ For example, in sample of 24 Russian defence sector enterprises, $50 \%$ of them were those who pursued the fragile adjustment driven by the top manager who does not seek the benefits and obligations of network participation (Kuznetsov, 1997, p. 25). However, Kuznetsov holds that the prevailing attitude is to carve out new networks combining the viable elements of the old and a closer association with banks, trading companies and other agents of the nascent private sector(Kuznetsov, 1997). Despite this it should be borne in mind that there are knowledge and innovation links in CEECs which are not of the recombination type as analysed by Stark (1997).
} 
complement technology import. The core of these dynamics should be strong $R \& D$

and innovation activities of domestic enterprises.

\section{References:}

Alange, Svereker; Jacobsson, Staffan; Konvolalov, Anfrey; Oumansky, Igor and Surina, Alll, 1995. St. Petersburg Techno-Economic System for Flexible Manufacturing: A competitive analysis in an international perspective, Chalmers Institute of Technology, mimeo

Amman, A. and Cooper, J., 1982. Industrial Innovation in the Soviet Union. New Haven, CT and London: Yale University Press.

Amsden, A.H. and Hikino, T., 1994. Project Execution Capability, Organisational Know How and Conglomerate Corporate Growth in Late Industrialisation, Industrial and Corporate Change, Vol.3, No.1, 149-72.

Aven, P., 1992. Economic reform in bargaining economy, In M. Kovacs and M. Tardos (eds), Reform and Transformation in Eastern Europe: Soviet-type Economies on the Threshold of Change, Routledge: London.

Balazs, Katalin, 1997. Is there any future for the Academies of Sciences ? In Dyker, D.A. (ed.) The Technology of Transition: Science and Technology Policy for Transition Countries, Budapest: Central European University Press.

Barham. K. and Heimer, C., 1998. ABB: The Dancing Giant - Creating the globally connected corporation, Financial Times/Pitman Publishing, London.

Bell, Martin, 1997. The Metallurgical Institutes: Sector Report, Phare Project: Restructuring of the S\&T Systems in Romania, Phase II, SPRU.

Bernstein, David (ed.), 1997. Co-operative Business Ventures Between US Companies and Russian Defence Enterprises, Stanford: Center for International Security and Arms Control, Institute for International Studies, Stanford University.

Bitzer, J. and von Hirschhausen, C., 1998. Shipbuilding: Final Report - 'Industrial restructuring', TSER project 'Restructuring and reintegration of S\&T systems in economies in transition', German Institute for Economic Research, Berlin, September.

Bitzer, Juergen, 1997. The Computer Software Industry in East and West: Do Eastern European Countries Need a Specific S\&T Policy ? DIW Discussion Paper No. 149, Berlin: German Institute for Economic Research.

Bitzer, Juergen, 1997b. The Computer Industry in East and West: Do Eastern European Countries Need a Specific S\&T Policy ? DIW Discussion Paper No. 148, Berlin: German Institute for Economic Research.

Bitzer, Juergen, 1998. Computers: Final Report - 'Industrial restructuring', TSER project 'Restructuring and reintegration of S\&T systems in economies in transition', German Institute for Economic Research, Berlin, September.

Bitzer, Juergen, 1998b. Software: Final Report - 'Industrial restructuring', TSER project 'Restructuring and reintegration of S\&T systems in economies in transition', German Institute for Economic Research, Berlin, September.

Blanchard, O.J., Froot, K.A, and Sachs, D.J. (eds), 1994. The transition in eastern Europe, Chicago: Chicago University Press

Buckle, J Peter and Ghauri, N. Pervez (eds), 1993. The Economics of Change in East and Central Europe: Its impact on International Business, London: Academic Press.

CERNA, 1996. Opportunities for regional co-operation for the European steel industry, Final Report, CERNA, Ecoles des Mines, Paris,

Chandler, Alfred, 1993. Organisation capabilities and industrial restructuring: a historical analysis, Journal of Comparative Economics, 17 (2), 309-37.

Charpiot-Michaud, Frederique, 1998. Restructuring the food processing industry in Eastern Europe for international competition: economic analysis with special reference to the role of 
S\&T policy in east and West, Final report - 'Industrial restructuring', TSER project 'Restructuring and reintegration of S\&T systems in economies in transition', German Institute for Economic Research, Berlin, September.

Chavance, Bernard, 1995. Hierarchical Forms and Co-ordination Problems in Socialist Systems, Industrial and Corporate Change, Vol. 4, No. 1, 271-291.

Constantellou, Natasha, 1997. Transformation dynamics in southern and eastern Europe: the emerging advanced communication networks and services, unpublished DPhil thesis, SPRU, University of Sussex.

Cronberg, Tarja, 1994. The Perm region's approach to defence conversion - and why regional initiatives do not seem to succeed in Russia, Paper presented at the Workshop on the conversion of Russian defence sector, Moscow, Unit of Technology Assessment, Technical University of Denmark, Lyngby.

David, Paul A. and Foray, D., 1995. Accessing and Expanding the Science and Technology Knowledge Base, STI Review, OECD, Paris.

de Wit, Alexander and Monami, Eric, 1993. Understanding the Former Soviet market: An Interaction Approach, In Buckle, J Peter and Ghauri, N. Pervez (eds) The Economics of Change in East and Central Europe: Its impact on International Business, London: Academic Press pp.

EBRD, 1994. Transition Report 1994, London: European Bank for Reconstruction and Development.

EBRD, 1995. Transition Report 1995: Investment and enterprise development, European Bank for Reconstruction and Development, London.

EBRD, 1996. Transition Report 1996: Infrastructure and savings, London: European Bank for Reconstruction and Development.

EC, 1995. Cohesion and the development challenge facing the lagging regions, Regional development studies, No. 24, Office for Official Publications, Luxembourg.

Edquist, C. (ed.), 1997. Systems of Innovation: Technologies, Institutions and Organisations, London: Pinter Publisher.

Freeman, Chris, 1987. Technology Policy and Economic Performance - Lessons from Japan, London: Pinter Publishers.

Freeman, Chris, 1999. Catching-up and Innovation Systems: Implications for Eastern Europe, In Knell, M.; Hutschenreiter, G. and Radosevic, S. (eds) Restructuring of Innovation Systems in Central Europe and Russia, Edward Elgar, 1999 (forthcoming)

Freinkman, Lev, 1995. 'Financial-industrial Groups in Russia: Emergence of Large Diversified Private Companies', Communist Economies \& Economic Transformation, Vol.7, No.1, 51-66.

Gaidar, Egor, 1990. Economic reforms and hierarchical structures (Ekomomicheskije reformi i hijerarchischeskije strukturi), Moskva, Nauka

Gokhberg, L., 1997. 'Transformation of the Soviet R\&D System', in Gacs, Gokhberg and Peck (eds) Russian Applied R\&D: Its Problems and Prospects, IIASA, Economic Transition and Integration Project, Laxenbourg.

Gorbatova, Larisa, 1995. Formation of Connections between Finance and Industry in Russia: Basic Stages and Forms, Communist Economies \& Economic Transformation, Vol.7, No.1. Grabher, Gernot, 1997. Adaptation at the Cost of Adaptability? Restructuring the Eastern German Regional Economy, In Grabher, Grabher and Stark, D. (eds) (1997) Restructuring Networks in Post-Socialism: Legacies, Linkages, and Localities, Oxford: Oxford University Press.

Grabher, Grabher and Stark, D. (eds), 1997. Restructuring Networks in Post-Socialism: Legacies, Linkages, and Localities, Oxford: Oxford University Press.

Granovetter, Mark, 1985. Economic Action and Social Structure: The Problem of Embededdnes, American Journal of Sociology, Vol, 91, No. 3: 481-510.

Guerrieri, Paolo, 1999. 'Technology and structural change in trade of the CEE countries', In Dyker, D. and S. Radosevic (eds) Quantitative Studies for Science \& Technology Policy in Countries of Central and Eastern Europe, NATO Science Series, IOS Press, Oxford, 1999 (forthcoming) 
Guerrieri, Paolo, 1999. Technology, structural change and trade patterns of eastern Europe, In Hutschenreiter, Knell and Radosevic (eds): Restructuring of Systems of Innovation in Eastern Europe, Aldershot: Edward Elgar (forthcoming)

Hanson, Phil and Pavitt, Keith, 1987. The Comparative Economics of Research, Development and Innovation in East and West: a Survey, Chur: Harwood Academic Publishers.

Hanson, Philip, 1995. Regions, Local Power and Economic Change in Russia, In Smith, Alan (ed.) Challenges for Russian Economic Reform, The Royal Institute of International Affairs, London.

Hardy, Jane, 1997. Transnational, corporate strategies and locality in Poland: the limits of instituionalism, Paper presented at the conference of the European Association for Evolutionary Political Economy, November, Athens,

Hare, Paul and Oakey, Ray, 1993. The Diffusion of New process Technologies in Hungary: Eastern European Innovation in Perspective, London: Pinter Publishers.

Havas, Attila, 1996. 'International Co-operative agreements in Hungary in the mid-1990s: Evolution, Organisational Forms and Industry Characteristics', Paper prepared for the first Workshop of an ACE Project 'Technology Transfer or Blockaded Entry: International Cooperative agreements in the Central European economies in transition'. Maastricht, 17 June.

Havas, Attila, 1998. International Cooperative Agreements in Hungary in the Mid-1990s: Evolution, Organisational Forms and Industry Characteristics, IKU, Innovation Research Centre, Budapest, mimeo

Havas, Attilla, 1997. 'Foreign direct investment and intra-industry trade: the case of the automotive industry in Central Europe', In Dyker, David.(ed.) Technology of Transition. Science and Technology Policies for Transition Countries, Budapest: Central European University Press.

Hobday, Michael, 1994. Innovation in East Asia, London: Edward Elgar.

Hunya, Gabor, 1996a. 'Foreign direct investment in transition countries in 1995', Vienna Institute Monthly Report, No.1, 2-8.

Hunya, Gabor, 1996b. Foreign Direct Investment in Hungary: a Key Element of Economic Modernization, Research Report, No. 226, The Vienna Institute for Comparative Economic Systems, February

INIOR, 1996. Finansovo - promishlenije groupi. Ocenka perspektiv sozdanija i ispolzovanija mehanizma FPG dlja optimizaciji dejateljnosti otrasli, Institute isledovanija organizovanih rinkov, Moskva.

Jeffries, Ian, 1993. Socialist Economies and the Transition to the Market - A Guide, London and New York: Routledge.

Kalinowski, Tomasz and Sobczak, Darius, 1996. Przemiany strukturalne gospodarki regionu gdanskiego, Instytut Badan and Gospodarka Rynkowa, Gdansk.

Karlova, Enna, 1996. Russia: Financial - Industrial Groups (FIGs), Industrial Policy and Competition, World Bank, mimeo, August 30.

Kekic, Laza, 1996. Assessing and Measuring Progress in the Transition, Economies in Transition: Regional Overview, EIU Country Forecast, 2nd quarter 1996, London: Economist Intelligence Unit.

Kenway, Peter, 1994. The Concentration of Ownership and its Implications for Corporate Governance in the Czech Republic, Discussion Paper No. 288, Department of Economics, University of Reading.

Knell, M., Hutschenreiter, G. and Radosevic, S. (eds), 1999. Restructuring of Systems of Innovation in Eastern Europe, Aldershot: Edward Elgar (forthcoming)

Kolankiewicz, George, 1996. Social capital and social change, British Journal of Sociology, Vol. 47, No. 3, 427-441.

Kontkiewicz-Chachulska, Hanna and Phan, Denis, 1996. From path-dependent processes of structural change to a diversity of market-models in central European countries' telecommunications, Paper presented to the XI International Telecommunication Society Conference 'Telecommunications: an engine of social and economic development', 16-19 June, Seville. 
Krykov, Valery and More, Arild, 1996. The New Russian Corporatism? A Case Study of Gazprom, Post-Soviet Business Forum, London: The Royal Institute of International Affairs.

Kubielas, Stanislaw, 1997. Transformation of technology patterns of trade in the CEE countries, In Dyker, D.A. and Radosevic, S. (eds) Quantitative Studies for Science \& Technology Policy in Countries of Central and Eastern Europe, NATO Science Series, IOS Press, Oxford, 1999 (forthcoming)

Kubielas, Stanislaw, 1998. International Cooperative Agreements in Poland in the mid-1990s: Evolution, Organisational Forms and Industry Characteristics, Faculty of Economic Science, Warsaw University, Warsaw, mimeo.

Kuznetsov, Yevgeny, 1994. Grafting market institutions into transition economies: discontinuity vs. path dependency. The case of Russia, Institute of Economic Forecasting, Moscow: MacArthur Foundation Project.

Kuznetsov, Yevgeny, 1997. Learning to Learn: Emerging patterns of enterprise behaviour in the Russian defence sector, 1992-1995. in Judith B. Sedaitis (ed) Commercialising High Technology: East and West, Lanham, Boulder, New York, London: Rowman \& Littlefield Publishers.

Kuznetsov, Yevgeny, 1997b. Knowledge Assessment: alternative concept and pilot projects, Washington: World Bank, mimeo.

Landesmann, M. and Burgstaller, J., 1997. Vertical Product Differentiation in EU Markets: the Relative Position of East European Producers, Research Reports, No. 234, The Vienna for Comparative Economic Studies (WIIW).

Landesmann, Michael, 1997. Emerging patterns of European Industrial Specialization: Implications for Labour Market Dynamics in Eastern and Western Europe, Research Reports, No. 230, The Vienna for Comparative Economic Studies (WIIW).

Lorentzen, Anne, 1996. Crisis, institutions, and technological change in the BAZ County, Hungary, Paper presented at the 8th General EADI Conference, Vienna.

Lundvall, Bengt-Åke (ed.), 1992. National Systems of Innovation - Towards a Theory of Innovation and Interactive Learning, London: Pinter Publishers.

Martens, John, 1991. Measuring Soviet Performance in Industrial Innovation: The Implementation of New Inventions, Paper prepared for: Technology and Transition in the USSR, A NATO Science Policy Workshop, University of Birmingham, September.

McDermott, A. Gerald, 1997. Renegotiating the Ties that Bind: The Limits of Privatisation in the Czech Republic, In Grabher, Grabher and Stark, D. (eds) (1997), Restructuring Networks in Post-Socialism: Legacies, Linkages, and Localities, Oxford: Oxford University Press.

Meske, Werner, 1997. Wissenschaft und Wirtschaft in Ostdeutschland. In Spektrum der Wissenschaft, Internationale Editions Scientific American (in German), No. 12/96, Heidelberg 1996, 42-47.

Meske, Werner; Mosoni-Fried, Judith; Etzkowitz, Henry and Nesvetailov, Gennady A (eds), 1998. Transforming Science and Technology Systems - The Endless Transition? NATO Science Series 4/23, IOS Press, Amsterdam.

Mueller, Juergen, 1998. Restructuring of the Telecommunications sector in the West and the East and the Role of S\&T, Final Report - 'Industrial restructuring', TSER project 'Restructuring and reintegration of S\&T systems in economies in transition, Berlin School of Economics (FHW), Berlin, September.

Mueller, Karel, 1997. The Institutional Transformation of S\&T System in the Czech Republic Directed to a New (National) Innovation System, Paper prepared within the project 'Restructuring and reintegration of S\&T systems in economies in transition', Berlin: Wisensschaft Zentrum.

Murrel, Peter, 1990. The Nature of Socialist Economies. Lessons from Eastern European Foreign Trade, Princeton NJ: Princeton University Press.

Nelson, Richard (ed.), 1993. National Systems of Innovation: A Comparative Study, Oxford: Oxford University Press. 
Nelson, Richard, 1997. The Evolution of Competitive or Comparative Advantage: A Preliminary Report on a Study, IIASA Working Paper 96-21, Laxenbourg.

OECD, 1969. Science Policy in the USSR, Paris: OECD

Pavitt, Keith and Patel, Pari, 1995. Corporate technology strategies and national systems of innovation, In Allouche Jean and Gerard. Pogorel (eds) Technology Management and Corporate Strategies: A Tricontinental Perspective, Elsevier Science B.V.

Pavitt, Keith, 1997. Transforming centrally planned systems of science and technology: the problem of obsolete competencies, In. Dyker, D.A. (ed.) Technology of Transition, Budapest: Central European University Press.

Prokop, E. Jane, 1995. Industrial Conglomerates, Risk Spreading and the Transition in Russia, Communist Economies \& Economic Transformation, Vol.7, No.1.

Radosevic, S. and Auriol, L., 1998. Patterns of Restructuring in Research, Development and Innovation Activities in Central and Eastern European Countries: Analysis Based on S\&T Indicators, Research Policy, 28, 351-376.

Radosevic, S. and Kutlaca, D., 1999. Technological 'Catching-up' Potential of Central and Eastern Euroep: AN Analysis Based on US Foreign Patenting Data, Technology Analysis \& Strategic Management, Vol. 11, No. 1, 95-111. (full version available as SPRU, STEEP Discussion Paper No. 42, http://www.sussex.ac.uk/spru)

Radosevic, Slavo, 1994. Strategic Technology Policy for Eastern Europe, Economic systems, Vol. 18, No. 2, December 1994, 87-116.

Radosevic, Slavo, 1997b. The Baltic Post-Socialist Enterprises and the Development of Organisational Capabilities, In Hood, Neil, Kilis, R. and Vahlne, J.E. (1997) Transition in the Baltic States: Micro-Level Studies, London: Macmillan Press.

Radosevic, Slavo, 1997c. Technology Transfer in Global Competition: The case of Economies in Transition, In. Dyker, D.A. (ed.) Technology of Transition, Budapest: Central European University Press.

Radosevic, Slavo, 1998. National Systems of Innovation in Economies in Transition: Between Restructuring and Erosion, Industrial and Corporate Change.

Radosevic, Slavo, 1998b. Defining Systems of Innovation. A Methodological Discussion, Technology in Society 20, 1998, 75-86.

Radosevic, Slavo, 1999. Restructuring and reintegration of S\&T systems in economies in transition, Final Report, TSER project, SPRU, Brighton.

Radosevic, Slavo, 1999b. Prospects for Building Regional Technology Policy in Central and Eastern Europe, In Morgan, Kevin and Nauewealers, C. (eds) Regional Technology Strategies, Stationaery Office Press, London, forthcoming.

Radosevic, Slavo, 1999c. 'Alliances and the Emerging Patterns of Technological Integration and Marginalisation of Central and Eastern Europe in Global Economy, In Dyker, David. Foreign Direct Investments in Russia and Ukraine, London: Edward Elgar.

Radosevic, Slavo, 1999d. Growth of enterprises through alliances in central Europe: the issues in controlling access to technology, market and finance, Paper submitted to Journal of International Business Studies, SPRU, Brighton.

Richet, X. and Bourassa, F., 1998. Restructuring of the East European Car Industry. Final Report - 'Industrial restructuring', TSER project 'Restructuring and reintegration of S\&T systems in economies in transition, ROSES, Universite Paris I, September.

Salmi, Asta and Moller, Kristian, 1993. Business Strategies During Dramatic Environment Change: a Network Approach for Analysing Firm-Level Adaptation to the Soviet Economic reform, In Buckle, J Peter and Ghauri, N. Pervez (eds), op. cit, pp.

Sandberg, Mikael, 1989. Learning from Capitalists: A Study of Soviet Assimilation of Western Technology, Stockholm: Almqvist \& Wiksell.

Schmidt, Klaus-Dieter, 1998. Emerging East - West Collaborative Networks: An Appraisal, Kiel Working Paper No. 882, The Kiel Institute of World Economics, October.

Sedaitis, B. Judith, 1997. Commercialising High Technology: East and West, Lanham, Boulder, New York, London: Rowman \& Littlefield Publishers

Shaw, Brian, 1996. Networking in Russian aerospace industry, R\&D Management 26, 3, 255 265. 
Stark, David, 1996. Heterarchy: Asset Ambiguity, Organisational Innovation, and the Postsocialist Firm, Working Paper 96-3, Department of Sociology, Cornell University, Ithaca.

Stark, David, 1997. Recombinant Property in East European Capitalism, In Grabher, Gernot and Stark, D. (eds), Restructuring Networks in Post-Socialism: Legacies, Linkages, and Localities, Oxford: Oxford University Press

Starodubravskaya, Irina, 1995. Financial - Industrial Groups: Illusions and Reality, Communist Economies \& Economic Transformation, Vol.7, No.1, 5-19.

Swaan, Wim, 1995. Capabilities and Competitiveness of the Hungarian Economy, paper presented at the conference 'Hungary: Towards a Market Economy', Budapest, Hungarian Academy of Sciences, 20-21 October.

Szalavetz, Andrea, 1997. Sailing before the wind of globalization. Corporate Restructuring in Hungary, Working Paper No. 78, April, Budapest: Institute for World Economy.

Toth, G. Laszlo, 1994. Technological Change, Multinational Entry and Re-Structuring: The Hungarian Telecommunications Equipment Industry, Economic Systems, vol. 18, No. 2, 179-198.

von Hippel, Eric, 1990. The Sources of Innovation, Oxford: Oxford University Press.

von Hirschhausen, Christian, 1996. Du Combinate socialist a l'enterprise capitaliste - Une analyse des reformes industrielles en Europe de l'Est, Paris: l'Harmattan.

von Hirschhausen, Christian, 1996b. 'Industrial Restructuring in Ukraine: from socialism to a planned economy’, DIW Discussion Paper No.144, Berlin: German Institute for Economic Research.

von Hirschhausen, Christian, 1996c. Deregulation and Enterprization in Central and Eastern European Telecommunication - A Benchmark for the West ?, DIW Discussion paper No. 145, Deutsches Institut fur Wirtschaftsforschung, Berlin.

von Tunzelmann, Nick, 1995. Technology and Industrial Progress. Foundations of Economic Growth, London: Edward Elgar.

Vorobjev, Alexander, 1996. An Industry Perspective: The Aviation Industry, In Kuznetsov, Y., Musienko, I. and Vorobjev, A. Learning to Restructure: Studies of Transformation in the Russian Defence Sector, Bonn International Centre for Conversion, paper 3, June, Bonn.

World Bank, 1996. World Development Report 1995: From Plan to Market, Washington DC: World Bank. 